\title{
Reactivity of Rare Earth Metal Porphyrins/Phthalocyanines in Acid Media
}

\author{
Tatyana N. Lomova, ${ }^{a} @$ Marija E. Klyueva, ${ }^{\mathrm{b}}$ and Oskar I. Koifman ${ }^{\mathrm{a}, \mathrm{c}}$ \\ ${ }^{\mathrm{a}}$ G. A. Krestov Institute of Solution Chemistry of the Russian Academy of Sciences, 153045 Ivanovo, Russia \\ ${ }^{\mathrm{b}}$ Ivanovo State Medical Academy, 153000 Ivanovo, Russia \\ 'Ivanovo State University of Chemistry and Technology, Research Institute of Macroheterocycles, 153000 Ivanovo, Russia \\ @Corresponding authorE-mail: tnl@isc-ras.ru
}

\begin{abstract}
Synthesis, structure, spectral properties and behavior in acid media of acido phthalocyanine complexes $(X)_{n-2} M P c$, double- and triple-decker phthalocyanine and porphyrin complexes $M(H P c)(P c), M(P c){ }_{2}, M_{2}(P c)_{3}$, and $M(P)_{2}, M_{2}(P)_{3}$ ( $M$ - lanthanide or actinide cation) were explored using UV-visible, IR, NMR spectroscopy and chemical kinetics. Kinetic equations, stoichiometric mechanisms of complexes demetallation and stability-structure relations were established.
\end{abstract}

Keywords: Phthalocyanines, porphyrins, complexes, double- and triple-deckers, synthesis, demetallation parameters, demetallation mechanism.

\section{Реакционная способность комплексов редкоземельных металлов с порфиринами и фталоцианинами в кислых средах}

\author{
Т. Н. Ломова, ${ }^{\text {a@ }}$ М. Е. Клюева, ${ }^{\mathrm{b}}$ О. И. Койфман ${ }^{\mathrm{a}, \mathrm{c}}$ \\ анститут химии растворов им. Г.А. Крестова РАН, 153045 Иваново, Россия \\ ${ }^{\mathrm{b}}$ Ивановская государственная медииинская академия, 153000 Иваново Россия \\ 'Ивановский государственный химико-технологический университет, НИИ макрогетерочиклических соединений, \\ 153000 Иваново, Россия \\ @E-mail: tnl@isc-ras.ru
}

Синтез, спектроскопия, молекулярная структура и поведение в кислотах (ацидо)(фталоцианинато), (фталоцианинато)/(порфиринато)комплексов лантанидов(III), тория и урана(III)/(IV) двух- и трехпалубного строения изучены с использованием УФ-видимой, ИК, ЯМР-спектроскопии и химической кинетики. Расширено понимание взаимосвязи между структурой и стабильностью комплексов.

Ключевые слова: Фталоцианины, порфирины, комплексы, двух- и трехпалубные комплексы, синтез, условия деметаллирования, механизм деметаллирования. 


\section{Introduction}

Rare earth metal porphyrins and phthalocyanines, including compounds with double- and triple-decker structure, together with their synthesis and properties, are reviewed in several works. ${ }^{[1-8]}$ Lanthanide cations having large radius give phthalocyanine complexes of structures $(\mathrm{X})_{\mathrm{n}-2} \mathrm{MPc}, \mathrm{M}(\mathrm{Pc})_{2}, \mathrm{M}_{2}(\mathrm{Pc})_{3}$ ( $\mathrm{Pc}-$ phthalocyanine dianion). Double-decker porphyrins exist in both in $\mathrm{PM}^{\mathrm{III}} \mathrm{P}$ in the case of $\mathrm{Sc}, \mathrm{Y}, \mathrm{Ln}$ and in $\mathrm{PM}^{\mathrm{IV}} \mathrm{P}$ in the case of cerium, thorium, uranium. Diphthalocyanines (double-decker phthalocyanines) of lanthanides $\mathrm{Ln}^{3+}$ could be obtained in both mono-protonated form, $\operatorname{Ln}(\mathrm{HPc})(\mathrm{Pc})$, where the threecharged $\mathrm{Ln}^{3+}$ cation replaces three protons of $\mathrm{NH}$ bonds and the fourth proton remains unsubstituted and in an oxidized radical form, $\operatorname{Ln}(\mathrm{Pc})_{2}{ }^{\bullet}$, where one $\pi$-electron is moved off and the $\mathrm{H}$ atom is absent. ${ }^{[9,10]}$ Double-decker cerium, thorium and uranium porphyrins exist in one form $\mathrm{PM}^{\mathrm{IV}} \mathrm{P}$. Tripledecker porphyrin and phthalocyanine complexes are formed by cations with a formal charge $3+$.

Synthesis of metallophthalocyanines with sandwich structure was described for the first time in $1965,{ }^{[11]}$ then in 1971 and 1974. ${ }^{[12,13]}$ The results of works ${ }^{[14-18]}$ prove a molecular structure of both double-decker and triple-decker rare earth metal phthalocyanines. X-Rray crystallography data for triple-decker complexes are not numerous ${ }^{[19,20]}$ whereas double-decker complexes including mixed (phthalocyaninato)(porphyrinato) complexes have been studied intensively. $[15-17,20-28]$ The results of molecular structure studying by means of density functional theory calculations or by systemizing of vibrational characteristics of bis- and tris-[(na)phthalocyaninato] and mixed (porphyrinato)[(na)phthalocyaninato] complexes ${ }^{[26,29]}$ were published. Rare earth metal doubledecker and triple-decker complexes with different phthalocyanine and porphyrin macrocycles in the same molecule are constructed. ${ }^{[30-34]}$ Researches of both the first sandwich-type rare earth metal double-decker complexes with $N$-confused porphyrinato and phthalocyaninato ligands ${ }^{[35]}$ and (phthalocyaninato)/(phthalocyaninato)(porphyrinato) rare earth(III)cadmium(II) quadruple/quintuple/sextuple-decker complexes have been started. ${ }^{[36-40]}$

Spectral and applied properties of the complexes are studied as a rule. Porphyrin and phthalocyanine double- and triple-decker complexes exhibit promising properties such as high stability of neutral and oxidized forms, solubility in organic solvents and ability to self-organization in solid layers. ${ }^{[4-44]}$ Lanthanide/actinide porphyrin/phthalocyanine complexes with double- and triple-decker structures can be used as components of new materials. Functional substitution of sandwich-type complex molecules lead to new functional molecular materials as optically active materials, FETs, SMMs. ${ }^{[45-54]}$ From the point of possibility of practical use of the compounds, their stability to chemical, thermal and photochemical influence is very important. Intensive studying ${ }^{[55,56]}$ clearly revealed high stability and its dependence on molecular structure for porphyrin/ phthalocyanine acido metal complexes. However, despite the synthesis and structural investigations of numerous porphyrin/phthalocyanine rare earth metal double-decker and triple-decker complexes, less attention has been devoted to their chemical stability.
Synthesis, structure, spectra and behavior in acid media of acido(phthalocyaninato), bis/tris(phthalocyaninato) and bis/tris(porphyrinato) rare earth(III) complexes were explored in the present work. The greatest attention is given to consideration of the ways of increasing the phthalocyanine complex stability. Kinetics and mechanisms of dissociation (demetallation) of the complexes are under discussion. We hope that the present results will attract interest for the creation of new functional materials based on rare earth multipledecker complexes with phthalocyanine/porphyrin ligands.

\section{Experimental}

Complexes of lanthanides (X)LnPc were synthesized from $\mathrm{Li}_{2} \mathrm{Pc}$ and corresponding lanthanide salt in a molar ratio 1:2.5 in boiling DMSO during 15-20 min. ${ }^{[57]}$ Reaction mixture was cooled and diluted with a double volume of water. A residue was filtered, washed with water and air-dried. An yield was $c a .90 \%$. Li 2 Pc was synthesized from $\mathrm{H}_{2} \mathrm{Pc}$ and butyllithium.

A mixture of $(\mathrm{X}) \mathrm{LnPc}, \mathrm{LnPc}_{2} \mathrm{H}, \mathrm{Ln}_{2} \mathrm{Pc}_{3}$ complex compounds with different content of individual complexes depending on the metal nature is obtained when synthesizing lanthanides phthalocyanines according to traditional methods..$^{[10,58]}$ That is when heating $o$-phthalonitrile with a rare earth metal salt in 8:1 molar ratio at $563 \mathrm{~K}$ during 1 hour. A product was dissolved in $500 \mathrm{~mL}$ of DMF and filtered. A solution was chromatographed on alumina (40/250) using ethanol. Two areas were obtained. The compounds of the first green and the second blue areas $\left(\mathrm{LnPc}_{2} \mathrm{H}\right.$ and $\mathrm{Ln}_{2} \mathrm{Pc}_{3}$ respectively) isolated by ethanol evaporating were dissolved in $\mathrm{DMF}$ and purified separately by second chromatography on alumina using ethanol.

$\mathrm{LnPc}_{2}{ }^{\cdot[59]}$ can be synthesized using method ${ }^{[60]}$ by interaction of $10 \mathrm{~g}$ of $o$-phthalonitrile with lanthanide acetate at $560-570 \mathrm{~K}$ during 1 hour. The blue-green product was endured in vacuum at $620 \mathrm{~K}$ for 1 hour, and then dissolved in DMF $(150 \mathrm{ml})$ with addition of hydrazine hydrate. The solution was filtered and was undergone electrolysis with constant current in a cell with graphite cathode and $\mathrm{Pt}$ anode. The crystals obtained were filtered, washed with acetone and dried at the temperature of $370 \mathrm{~K}$ in air. Electron absorption spectra of stable Ln diphthalocyanines in concentrated sulfuric acid have one wide band in the $400 \mathrm{~nm}$ region: $\lambda_{\max }, \mathrm{nm}(\log \varepsilon)$ in $17.7 \mathrm{M}$ $\mathrm{H}_{2} \mathrm{SO}_{4}$ are equal to 442 (4.47); 443 (4.51); 410 (4.32); 410 (4.00); 407 (4.00) for Nd, Pr, Sm, Eu and Gd complexes correspondingly.

Syntheses of double- and triple-decker actinide porphyrins are shown below in Results and Discussion.

$\boldsymbol{T h}(\boldsymbol{T P P})_{2}$. Electronic absorption spectrum (ethanol) $\lambda_{\max } \mathrm{nm}$ : $657,596,556$ and 516 with decreasing intensity in a number III $>$ II $>$ IV $>$ I. IR $\left(200-400 \mathrm{~cm}^{-1}\right) v \mathrm{~cm}^{-1}$ : vibrations of pyrrole rings 252 ( $v$ Ln-N, $\delta$ C-C-N), 384 ( $\delta$ C-C-N, v C-N), 395 ( $v$ C-N); Th-N 436. Found $\mathrm{C},(71.8 \pm 0.8) ; \mathrm{N},(7.2 \pm 0.3) ; \mathrm{H},(3.5 \pm 0.2)$; Th, $(16.1 \pm 0.3)$ $\%$. Calc. for Th(TPP) $)_{2}$ C, 72.51; N, 7.69; H, 3.87; Th, $15.92 \%$.

$\boldsymbol{T h}_{2}(\boldsymbol{T P P})_{3}$. Visible electronic absorption spectrum (benzene) $\lambda_{\max } \mathrm{nm}: 699,589,549,516$ with decreasing intensity in a number III $>$ IV > I > II. Found C, (67.9 \pm 0.7$)$; N, (6.9 \pm 0.3$) ; \mathrm{H},(3.5 \pm 0.2)$; Th, (20 \pm 2$)$; Calc. for $\mathrm{Th}_{2}(\mathrm{TPP})_{2}$. C, 68.86; N, 7.30; H, 3.68; Th, $20.16 \%$.

$\boldsymbol{U}^{I V}(\boldsymbol{T P P})_{2}$. Electronic absorption spectrum (ethanol) $\lambda_{\max } \mathrm{nm}$ (loge): 595.3 (4.03), 556.9 (4.33), 516.0 (4.01), 422.5 (4.84). IR $(\mathrm{KBr}) \vee \mathrm{cm}^{-1}$ : vibrations of pyrrole rings $802(\gamma(\mathrm{C}-\mathrm{H})), 997,1008$ $(v(\mathrm{C}-\mathrm{C})), \delta(\mathrm{C}-\mathrm{H}), v(\mathrm{C}-\mathrm{N})), 1372,1388(v(\mathrm{C}-\mathrm{N})), 1442(v(\mathrm{C}=\mathrm{N}))$, 2870, $2930(\mathrm{v}(\mathrm{C}-\mathrm{H}))$; vibrations of benzene rings 706, 724, and $754(\gamma(\mathrm{C}-\mathrm{H})), 1072$ and 1160, $1178(\delta(\mathrm{C}-\mathrm{H})), 1527,1578,1600$ $(v(\mathrm{C}=\mathrm{C})), 3050,3090(v(\mathrm{C}-\mathrm{H}))$; vibrations of the U-N bonds 430. ${ }^{1} \mathrm{H} \mathrm{NMR}\left(\mathrm{CDCl}_{3}\right) \delta \mathrm{ppm}: 8.93\left(\mathrm{~m}, 8 \mathrm{H}, J_{\mathrm{HH}}=10.1 \mathrm{~Hz}, o-\mathrm{C}_{6} \mathrm{H}_{5}\right) ; 8.19$ $\left(\mathrm{s}, 16 \mathrm{H}, \mathrm{C}_{4} \mathrm{H}_{2} \mathrm{~N}\right) ; 7.74\left(\mathrm{t}, 8 \mathrm{H}, J_{\mathrm{HH}}=7.75 \mathrm{~Hz}, m-\mathrm{C}_{6} \mathrm{H}_{5}\right) ; 7.72(\mathrm{t}, 8 \mathrm{H}$, $\left.J_{\mathrm{HH}}=7.44 \mathrm{~Hz}, p-\mathrm{C}_{6} \mathrm{H}_{5}\right) ; 7.52\left(\mathrm{t}, 8 \mathrm{H}, J_{\mathrm{HH}}=6.82 \mathrm{~Hz}, m-\mathrm{C}_{6} \mathrm{H}_{5}\right) ; 6.70$ $\left(\mathrm{m}, 8 \mathrm{H}, o-\mathrm{C}_{6} \mathrm{H}_{5}\right)$. Found: $\mathrm{U}, 16.1 \%$. Calc. for $\mathrm{U}^{\mathrm{IV}}(\mathrm{TPP})_{2}: 16.26 \%$. 
$\boldsymbol{U}^{I I I}{ }_{2}(\boldsymbol{T P P})_{3}$. Electronic absorption spectrum (benzene) $\lambda_{\mathrm{m}}$ nm (loge): 657.9 (4.40), 599.5 (4.36), 462.1(5.12), 422.3 (5.16). IR $(\mathrm{KBr}) \vee \mathrm{cm}^{-1}$ : vibrations of pyrrole rings $808(\gamma(\mathrm{C}-\mathrm{H})), 1000,1016$ $(v(\mathrm{C}-\mathrm{C})), \delta(\mathrm{C}-\mathrm{H}), v(\mathrm{C}-\mathrm{N})), 1375,1380(v(\mathrm{C}-\mathrm{N})), 1445(v(\mathrm{C}=\mathrm{N}))$, $2875,2950(\mathrm{v}(\mathrm{C}-\mathrm{H}))$; vibrations of benzene rings 704, 710, and 728 $(\gamma(\mathrm{C}-\mathrm{H})), 1080$ and 1158, $1185(\delta(\mathrm{C}-\mathrm{H})), 1528,1550$, and 1580, $1608(v(\mathrm{C}=\mathrm{C})), 3070,3100(v(\mathrm{C}-\mathrm{H}))$; vibrations of the U-N bonds 436. ${ }^{1} \mathrm{H}$ NMR $\left(\mathrm{CDCl}_{3}\right) \delta$ ppm: 9.97(d); $8.42(\mathrm{~m}) ; 8.24(\mathrm{~s}) ; 7.76(\mathrm{t})$; $7.74(\mathrm{t}) ; 7.71(\mathrm{t}) ; 7.68$ (t); 7.49 (t); 7.02 (d); 6.72 (d). Found: U, $19.8 \%$. Calc. for $\mathrm{U}_{2}^{\mathrm{III}}(\mathrm{TPP})_{3}: 20.57 \%$.

The kinetics of complex dissociation reactions was studied spectrophotometrically in the acid solvents of variable composition by the concentrations excess method. The experiment was carried out in a thermostatically controlled glass cell at the temperature of $298 \mathrm{~K}$ and higher. The temperature was measured to $\pm 0.1 \mathrm{~K}$. Changes in the absorbance of the solution were measured at the operating wavelengths. The effective rate constants of dissociation $\left(k_{o b s}, \mathrm{~s}^{-1}\right)$ obtained under the conditions of large excess of solvated protons with respect to the complex concentration were calculated by the first-order equation (1):

$$
k_{\text {obs }}=\frac{1}{\tau} \ln \frac{A_{0}-A_{\infty}}{A_{\tau}-A_{\infty}}
$$

Here $A_{\tau}, A_{0}, A_{\infty}$ are absorbances observed at present time, when $\tau=0$, and when a reaction had terminated, respectively*. The reaction order with respect to the acid concentration was determined from the $\log k_{\mathrm{ef}} v s .\left[\log C_{\mathrm{HX}}\right]$ plots as the slope of the regression line in three-five independent experiments. The activation parameters $E$ and $\Delta S^{\ddagger}$ of the complex dissociation were calculated using the Arrhenius equation and the basic equation of the transition state theory reduced to the form (2), respectively. Numerical value of $\Delta S^{\ddagger}$ was determined as the arithmetic mean of one calculated for all investigated temperatures. $E$ and $\Delta S^{\ddagger}$ were obtained with an accuracy $2-9 \mathrm{~kJ} / \mathrm{mol}$ and $8-28 \mathrm{~J} /(\mathrm{mol} \cdot \mathrm{K})$, respectively.

$$
\Delta S^{\ddagger}=19.1 \log k T+E / T-19.1 \log T-205
$$

\section{Results and Discussion}

\section{Acido Phthalocyanine Metal Complexes $(X)_{n-2} M P c$}

Varying acido ligand nature could change stability of the coordination compounds of this type. ${ }^{[61]}$ The study was carried out for both complexes of one and the same metal with a set of acido ligands $\mathrm{X}^{-}\left(\mathrm{Cl}^{-}, \mathrm{Br}^{-}, \mathrm{AcO}^{-}\right)^{[62]}$ and complexes of different metal cations of one type with one and the same $\mathrm{X}^{-}{ }^{[33]}$

Until now only a few crystal structures with trivalent metals have been described. In lutetium(III) monophthalocyanine derivative $\left[\left(\mathrm{H}_{2} \mathrm{O}\right)_{2}(\mathrm{AcO}) \mathrm{Lu}^{\mathrm{III}}(\mathrm{Pc})\right] \cdot \mathrm{H}_{2} \mathrm{O} \cdot \mathrm{CH}_{3} \mathrm{OH}$ the coordination geometry is a slightly distorted square antiprism. ${ }^{[63]}$ The donor atoms consist of four isoindole nitrogens of the phthalocyanine ring, two oxygen atoms of one acetate anion, and two oxygens of two water molecules. Acetate anion and two water molecules are at the same side of the macrocycle. The four $\mathrm{Lu}-\mathrm{N}$ iso-bond distances range from 2.333 to 2.359 $\AA$ with a mean value of $2.345 \AA$. The four isoindole nitrogen atoms of the phthalocyanine ring are coplanar. The Lu atom lies $1.26 \AA$ away from the $4 \mathrm{~N}$-iso mean plane.

(X)LnPc give molecular solutions in ethanol $\left(10^{-5}-10^{-4}\right.$ mol/l). A long wave absorption band $\left(\pi \rightarrow \pi^{*}\right.$ transition) position in UV-vis spectra of the complexes in this solvent as in other organic solvents (Table 1) is practically independent on metal and acido ligand nature.

This points to the existence of particles $\left[\left(\mathrm{C}_{2} \mathrm{H}_{5} \mathrm{OH}\right)_{\mathrm{n}-2} \mathrm{LnPc}\right]^{+}$ in the solution, where $n$ is the maximum coordination number of Ln at given conditions (Figure 1). Thus, ethanol is the fit medium for investigating the dissociation of the complexes in the presence of acid.

$\left[\left(\mathrm{C}_{2} \mathrm{H}_{5} \mathrm{OH}\right)_{\mathrm{n}-2} \mathrm{LnPc}\right]^{+}$dissociation leads to formation of $\mathrm{H}_{2} \mathrm{Pc}$ soluble in the reaction mixture, sediment formation is not observed during the reaction process:

$$
\begin{aligned}
& {\left[\left(\mathrm{C}_{2} \mathrm{H}_{5} \mathrm{OH}\right)_{\mathrm{n}-2} \mathrm{LnPc}\right]^{+}+2 \mathrm{AcOH} \rightarrow} \\
& \rightarrow \mathrm{H}_{2} \mathrm{Pc}+\left[\mathrm{Ln}\left(\mathrm{C}_{2} \mathrm{H}_{5} \mathrm{OH}\right)_{\mathrm{n}}\right]^{3+}+2 \mathrm{AcO}^{-}
\end{aligned}
$$

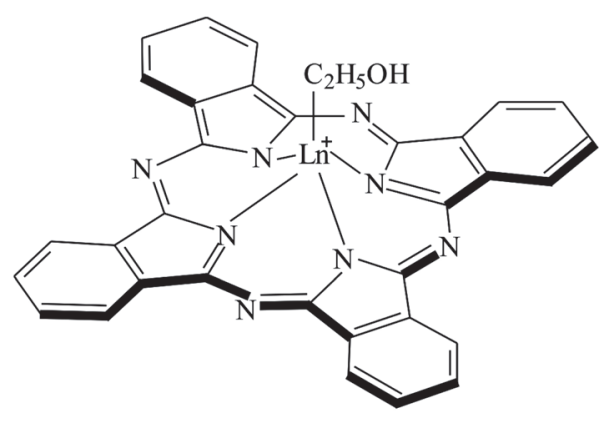

Figure 1. Structure of lanthanide (Tb-Lu) phthalocyanines in the ethanol solution.

Table 1. A long wave absorption band position $\left(\lambda_{\max }^{\mathrm{I}}, \mathrm{nm}\right)$ in UV-vis spectra of $(\mathrm{X}) \mathrm{LnPc}^{\mathrm{a}}$.

\begin{tabular}{cccccccc}
\hline Solvent & $(\mathrm{AcO}) \mathrm{TbPc}$ & $(\mathrm{AcO}) \mathrm{DyPc}$ & $(\mathrm{AcO}) \mathrm{HoPc}$ & $(\mathrm{AcO}) \mathrm{ErPc}$ & $(\mathrm{AcO}) \mathrm{TmPc}$ & $(\mathrm{Cl}) \mathrm{YbPc}$ & $(\mathrm{AcO}) \mathrm{LuPc}$ \\
\hline Ethanol & & 670.6 & & & & 670.6 & \\
DMSO & 676.9 & 674.9 & 678.6 & 674.6 & 673.4 & 677.5 & 673.8 \\
PhH & 671.5 & 671.9 & 672.6 & 672.6 & 677.5 & 674.3 & 674.3 \\
Acetone & 667.9 & 667.8 & 670.2 & 666.8 & 666.7 & 666.7 & 663.1 \\
Py & 675.2 & 675.4 & 674.4 & 674.4 & 675.7 & 674.4 & 674.4 \\
$\mathrm{PhCN}$ & 719.1 & 720.5 & 719.0 & 719.0 & 718.4 & 716.9 & 714.9 \\
& 691.2 & 690.6 & 691.2 & 691.2 & 691.2 & 691.2 & 691.2 \\
$\mathrm{CHCl}_{3}$ & 675.2 & 671.6 & 671.3 & 676.8 & 675.7 & 676.7 & 675.3 \\
\hline
\end{tabular}

${ }^{a}{ }_{\text {max }}^{\mathrm{I}}$ is equal to 671.5 and $669.2 \mathrm{~nm}$ for $(\mathrm{Cl}) \mathrm{CePc}$ in ethanol and $(\mathrm{AcO}) \mathrm{GdPc}$ in DMSO.

\footnotetext{
${ }^{*}$ For numerical values of effective rate constants of dissociation,
} see Online Supplementary Materials. 
The $k_{o b s}^{298}$ values for $\mathrm{Tb}-\mathrm{Yb}$ complexes (Table 1S) derived from extrapolation of $k_{o b s}$-temperature dependence are changing non-linearly with changing $\mathrm{AcOH}$ content in a wide range of the mixed solvent compositions (Figure 2 , Tables $1 \mathrm{~S}, 2 \mathrm{~S})$. That is why it is impossible to find a total kinetic equation for reaction (3) and true values of the rate constants $k$. The $k_{o b s}^{298}-f\left(C_{A c O H}^{0}\right)$ dependence for labile cerium and praseodymium phthalocyanines (Table $2 \mathrm{~S}$ ) is linear from 0 to 0.04 mole fractions of $\mathrm{AcOH}$ in ethanol:

$-d C_{(X) L n P c} / d \tau=k_{o b s} \cdot C_{(X) L n P c}=k \cdot C_{(X) L n P c} \cdot C_{A c O H}$

In this case a value of tangent of inclination angle of straight line in $k_{o b s}^{298}-f\left(C_{A C O H}^{0}\right)$ coordinates can be used as a universal (in regard to mixed solvent composition) criterion of the complex stability. Its value is equal $k=K_{a} \cdot k^{\prime}, K_{a}-$ acid ionization constant of $\mathrm{AcOH}$ in ethanol, $k^{\prime}-$ the rate constant of elementary reaction between (X)LnPc and AcOH. UV-vis spectra of phthalocyanine complexes with rare earth elements from $\mathrm{Tb}$ to $\mathrm{Lu}$ do not change when boiling the ethanol solutions of the compounds during a long time. This allows extrapolation of $k_{o b s}^{298}-f\left(C_{A c O H}^{0}\right)$ dependencies at $\mathrm{C}^{0}{ }_{\mathrm{AcOH}}>0.04$ mole fractions. Tangent of inclination angle of tangent line to curve drawn through the origin $(\operatorname{tg} \alpha)$ has the same meaning as $K_{a} \cdot k^{\prime}$ parameter in the case of phthalocyanine complexes with elements from $\mathrm{La}$ to $\mathrm{Gd}$. Thus, using $\operatorname{tg} \alpha$ values proportional to $k$ value for $\mathrm{Tb}-\mathrm{Lu}$ phthalocyanine complexes we obtain the dependence of the physical-chemical parameter of the complex from the lanthanide ordinal number $(Z)$ through the lanthanides row. That is shown in Figure 3. According to Figure 3 data the phthalocyanine lanthanides stability changes with $Z$ growth through concave curve with "gadolinium fracture" directed down. It must be pointed out that $k_{o b s}^{298}$ dependence from $Z$ for the same solvent composition has analogous view. The dependence under consideration has "canonical" type in a whole ${ }^{[60]}$ in spite of the complex composition of the investigated compounds and is analogous to the dependencies obtained when studying the stability of $\mathrm{Ln}^{3+}$ complexes with chelate and simple molecular ligands. It is known ${ }^{[64,65]}$ that "gadolinium fracture" is connected with peculiarities of $\mathrm{Ln}^{3+} f$-shells and namely is determined by contributions of spin and orbital angular moments of motion quantity of the base

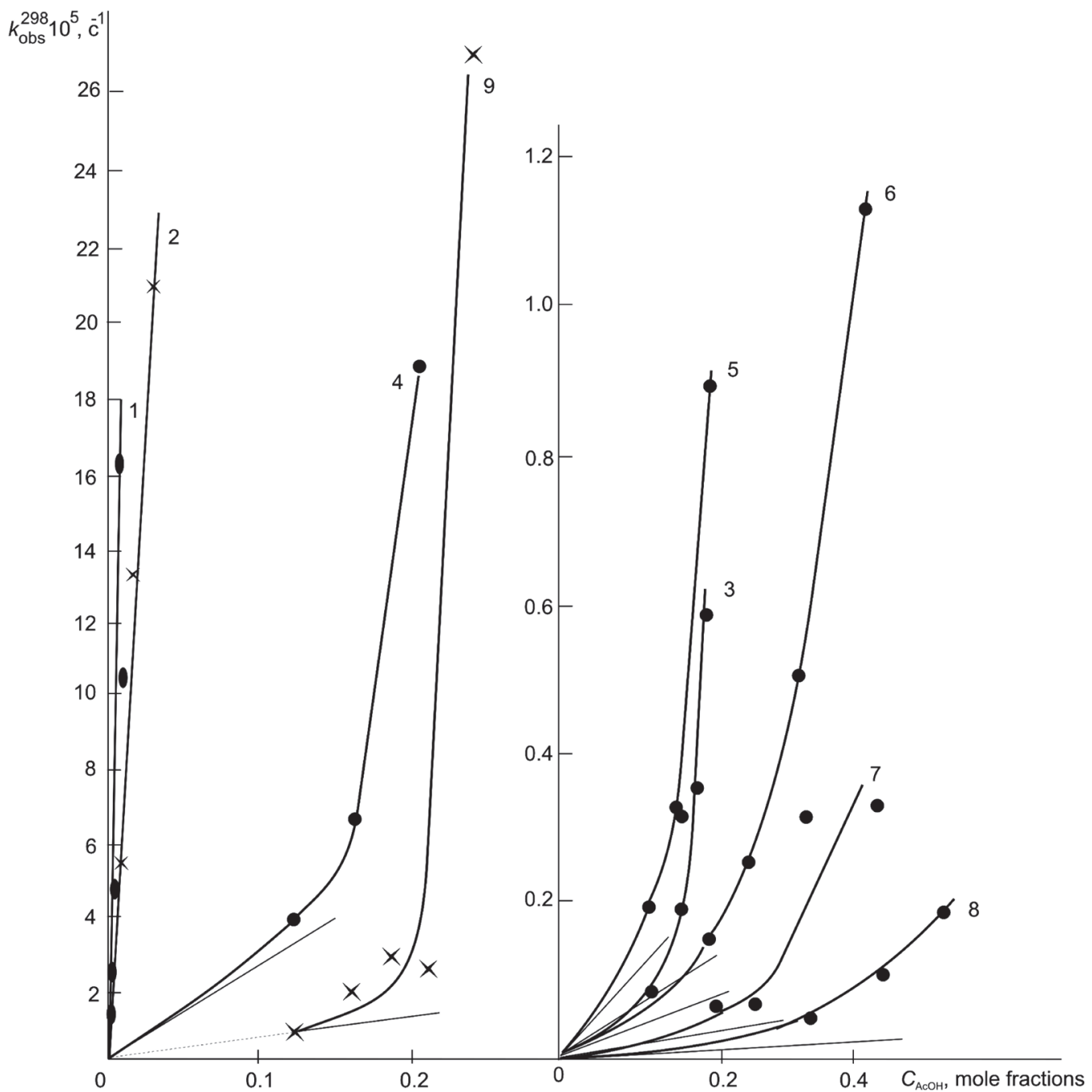

Figure 2. Dependences of dissociation rate constants of (X)MPc on initial AcOH concentration. M: 1 - Ce, 2 - Pm, 3 - Tb, 4 - Dy, 5 - Ho, 6 - Er, 7 - Tm, $8-\mathrm{Yb}, 9-\mathrm{Y}$ (for Ce and $\mathrm{Pm} k 10^{-3}$ ). 


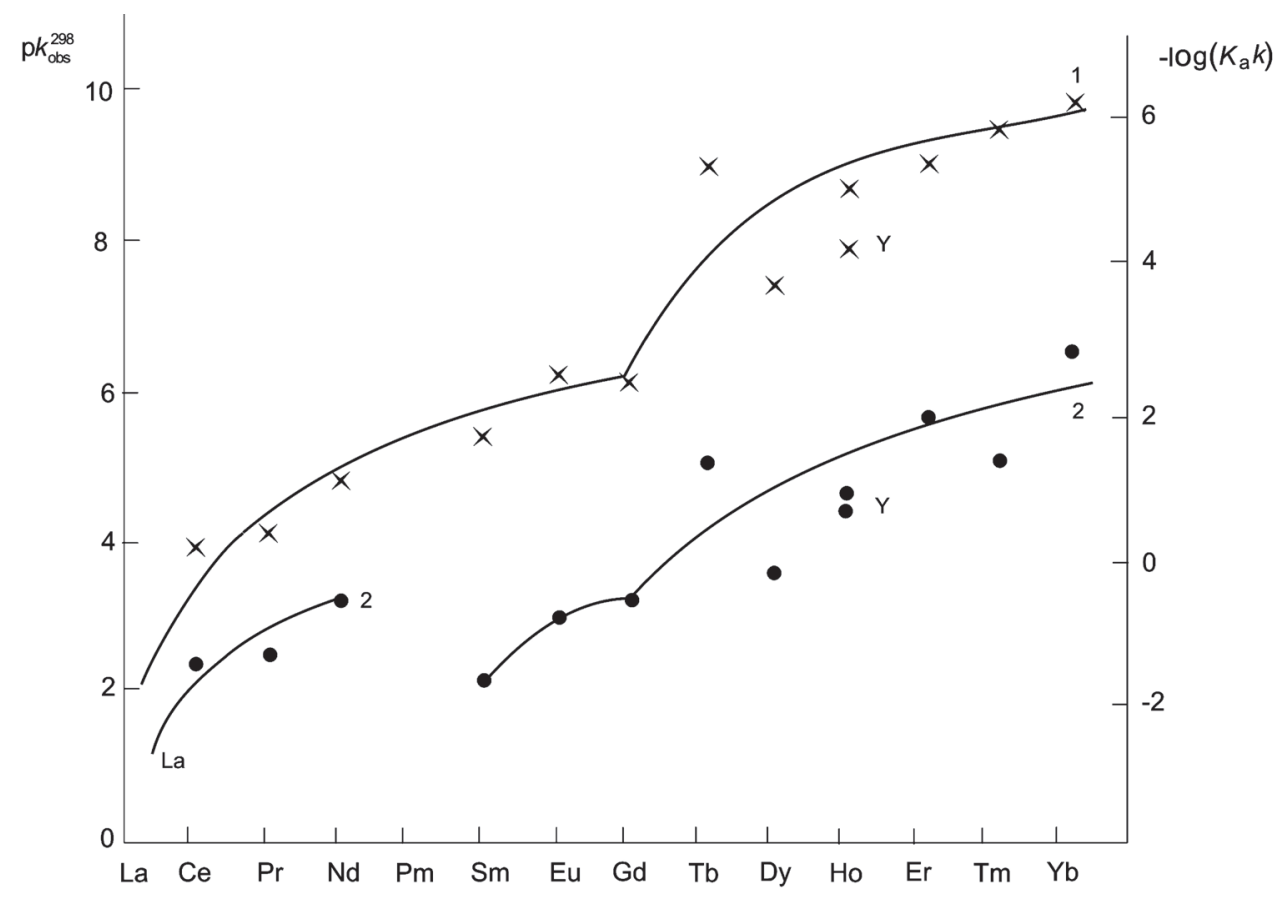

Figure 3. Dependences of $\log \left(K_{a} \times k\right)(1)$ and $\mathrm{p} k_{o b s}^{298}$ in ethanol-25\% AcOH (2) on lanthanides number. The $\mathrm{p} k_{o b s}^{298}$ in ethanol-1\% AcOH are shown for $\mathrm{La}-\mathrm{Pr}$.

lanthanide cation states. Detailed analysis of the dependency in Figure 3 shows that un-monotonous character of complex stability changing in lanthanides row is connected not only with the presence of partially filled $f$-orbitals in $(\mathrm{X}) \mathrm{LnPc}$ but with action of supplementary factors in the cases of complexes of $\mathrm{Ce}^{3+}$ and $\mathrm{Tb}^{3+}$ as well. Sharp increase in kinetic stability at the beginning of every sub-group - from La to $\mathrm{Ce}$ and from $\mathrm{Gd}$ to $\mathrm{Tb}$ - is the evidence of participation of $4 f^{1}$ - and $4 f^{8}$-electrons in dative $\pi$-bond $\mathrm{Ln} \rightarrow \mathrm{N}$ in the complex. This could be connected with striving of the pointed atoms for stable $f^{0}$ and $f^{7}$ configurations correspondingly and with presence of vacant $\pi$-orbital of low energy in the macrocycle.

The considered data show that rare earth element phthalocyanines are not pure ionic complexes. Covalent contribution to donor-acceptor interaction is carried out with participation of the $4 f$-orbitals as well as the external $s$-orbitals. The last is proved by comparison of stability of $\mathrm{M}^{3+}$ cation complexes with closed the $s^{2} p^{6}$ outer shell without $f$-orbitals $\left(\mathrm{Al}^{3+}, \mathrm{Sc}^{3+}, \mathrm{Y}^{3+}\right)$ and $\mathrm{La}^{3+}, \mathrm{Gd}^{3+}, \mathrm{Lu}^{3+}$ cation complexes with the $f^{0}, f^{\prime}$ and $f^{14}$ electron configurations. The stability series made with the help of acidities of media where the complexes dissociate with a measurable rate (Tables $1 \mathrm{~S}, 2 \mathrm{~S},{ }^{[66,67]}$ ) is the following: $\mathrm{Al}>\mathrm{Sc}>\mathrm{Y}>\mathrm{La}<\mathrm{Gd}<\mathrm{Lu}$. The complexes in the series are settled according with $Z$ increase. Deviation from monotony for $\mathrm{Gd}$ and $\mathrm{Lu}$ complexes is obviously connected with the so-called "f-effect" ${ }^{\text {[67] }}$ which is a decrease in energy of outer $s$-orbitals and their participation in formation of covalent bonds with the ligand orbitals.

Dependence of the dissociation rate of gadolinium and disprosium phthalocyanines with a set of different acido ligands $\mathrm{X}^{-}$upon $\mathrm{X}^{-}$nature (Figure 4 ) is the evidence of the acido ligand presence in the coordination shell of $\mathrm{Gd}$ and Dy (Figure 5). The dissociation rate increases in a series:
(OAc) GdPc $<(\mathrm{Br}) \mathrm{GdPc}<(\mathrm{Cl}) \mathrm{GdPc}$, corresponding to the electronegativity parameter of $\mathrm{X}^{-}$donor atom.

Summary Gd ${ }^{\mathrm{III}}$ and Dy ${ }^{\mathrm{III}}$ compex dissociation equations (equation 5) and rate equations (6 and 7 for Gd and Dy complexes correspondingly) are found:

$$
\begin{aligned}
& (\mathrm{X}) \mathrm{LnPc}+2 \mathrm{AcOH}=[(\mathrm{X}) \mathrm{Ln}]^{2+}+\mathrm{H}_{2} \mathrm{Pc}+2 \mathrm{AcO}^{-} \\
& -d C_{(X) G d P c} / d \tau=k C_{(X) G d P c} \cdot\left(C_{A c O H}^{0}\right)^{2} \\
& -d C_{(X) D y P c} / d \tau=k C_{(X) D y P c} \cdot C_{A c O H}^{0}
\end{aligned}
$$

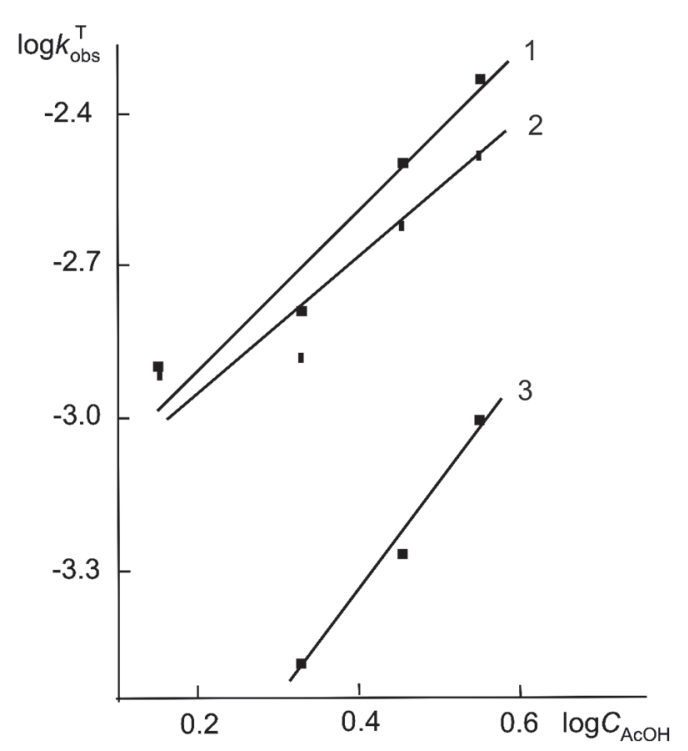

Figure 4. Dependences of dissociation rate constants of $(\mathrm{X}) \mathrm{GdPc}$ on initial $\mathrm{AcOH}$ concentration at $313 \mathrm{~K} . \mathrm{X}=\mathrm{Cl}(1)$, $\mathrm{Br}(2)$, OAc (3). 


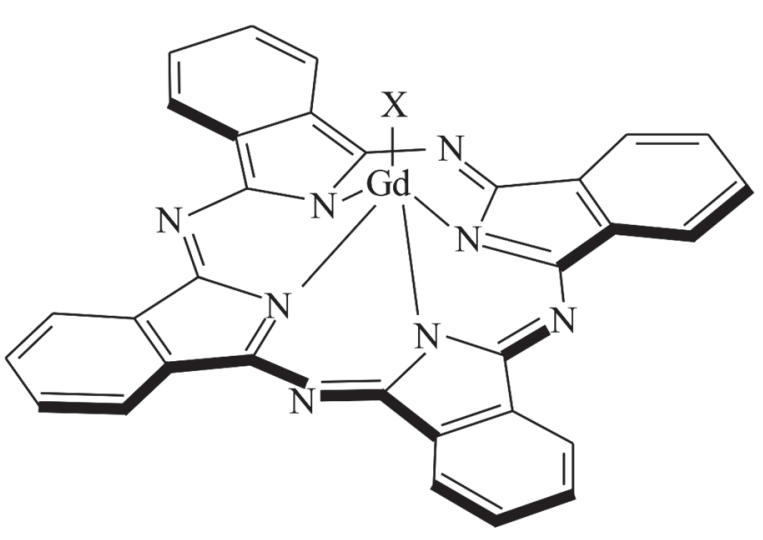

Figure 5. Structure of gadolinium phthalocyaninates in the solution.

Kinetic data for $\mathrm{Gd}^{\mathrm{III}}$ complexes indicate the equilibrium stage of acido ligand dissociation with its ousting to the second coordination sphere in contrast with Dy ${ }^{\mathrm{III}}$ complexes:

$$
(\mathrm{X}) \mathrm{GdPc}+\mathrm{AcOH} \stackrel{K}{\rightleftarrows}[(\mathrm{AcOH}) \mathrm{GdPc}]^{+} \cdot \mathrm{X}^{-}
$$

The limiting stage of M-N (N - the donor macrocycle atoms) bonds dissociation is differed in case of two complexes:

$$
\begin{aligned}
& {[(\mathrm{AcOH}) \mathrm{GdPc}]^{+} \mathrm{X}^{-}+2 \mathrm{AcOH} \stackrel{k}{\longrightarrow}} \\
& \stackrel{k}{\longrightarrow}(\mathrm{AcOH}) \mathrm{Gd}^{3+}+\mathrm{H}_{2} \mathrm{Pc}+2 \mathrm{AcO}^{-}+\mathrm{X}^{-} \\
& (\mathrm{X}) \mathrm{DyPc}+2 \mathrm{AcOH} \stackrel{k}{\longrightarrow}\left(\mathrm{X}^{-\mathrm{Dy}^{2+}}+\mathrm{H}_{2} \mathrm{Pc}+2 \mathrm{OAc}^{-}\right.
\end{aligned}
$$

Through the above mentioned series the dissociation rate constant value are changing in 24.4 and 2.4 times for Gd and Dy complexes correspondingly. Presence of dative $\pi$-bonds halogen - lanthanide or O-Ln (for acetic complexes) is obviously the reason for the low sensitivity of the Dy complex dissociation rate to counter ion $\mathrm{X}^{-}$. Kinetic stability of $(\mathrm{X}) \operatorname{DyPc}\left(k^{298}\right)$ is in 4.30 and 44 times (for $\mathrm{X}=\mathrm{AcO}^{-}, \mathrm{Br}$ and $\mathrm{Cl}^{-}$respectively) higher as compared with (X)GdPc due to reverse dative Dy-N $\pi$-bonds and the closer position of Dy cation to the macrocycle plane because of "lanthanide pressure" effect.

Thus, the complex stability could be changed in a necessary direction by acido ligand changing.

\section{Phthalocyanine Double-Deckers}

Double-decker structure of diphthalocyanine complexes of lanthanides was confirmed with X-ray crystallography data for $\mathrm{NdPc}_{2} \cdot{ }^{[14]}$ According to these data $\mathrm{Nd}$ atom in the molecule is situated between two parallel phthalocyanine ligands, which are turned to $45^{\circ}$ about each other. Each of eight Nd-N bond distances equals to 2.39-2.49 $\AA$. One of the phthalocyanine ligands has saucer-like conformation and the other is planar. The metallodiphthalocyanines exist in different crystalline modifications. For instance, $\alpha$-tetragonal and $\beta$-monoclinic forms of $\mathrm{Nd}(\mathrm{Pc})_{2}$ and $\beta$-monoclinic and $\gamma$-orthorhombic forms of $\mathrm{Sn}(\mathrm{Pc})_{2}$ are known. ${ }^{[68-70]} \mathrm{Nd}(\mathrm{Pc})_{2}$ also crystallizes in orthorhombic $\gamma$-form. Nowadays there is also information about structures of $\mathrm{Er}^{\mathrm{III}}(\mathrm{Pc})_{2},{ }^{[16]} \mathrm{Ce}^{\mathrm{IV}}(\mathrm{Pc})_{2}{ }^{[17]}$ and others.

Data on sandwich complexes the structure of which is studied by X-ray crystallography are listed in ${ }^{[2]}$. From the results, it is seen that the structure of double-decker phthalocyanine complexes for all the investigated compounds has the same type. The metal atom is coordinated by eight isoindole nitrogen atoms ( $N$-iso) and is situated between two phthalocyanine macrocycles. Macrocycles undergo distortion and become non-planar but saucer-shaped with benzene rings bent outward. The distortion degree as well as $\mathrm{M}-\mathrm{N}$-iso distances and rotation of the macrocycles with respect to one another are determined by nature and radius of the metal cation.

The results of the first quantitative investigations of stability in solutions of lanthanides phthalocyanines with composition lanthanide ion-phthalocyanine 1:2 were published in ${ }^{[59]}$. Diphthalocyanines of metals could be obtained in two forms. ${ }^{[9,10]}$ In this part the properties of sulfuric acid solutions and dissociation reactivity of oxidized diphthalocyanines of $\mathrm{Sc}, \mathrm{Y}, \mathrm{Pr}, \mathrm{Nd}$, lanthanides from $\mathrm{Sm}$ to $\mathrm{Lu}$ (Figure 6) are systematically considered. Properties of oxidized Ln diphthalocyanines are changing essentially when going along a series from La to Lu. That is why La and Y sub-groups will be described separately.

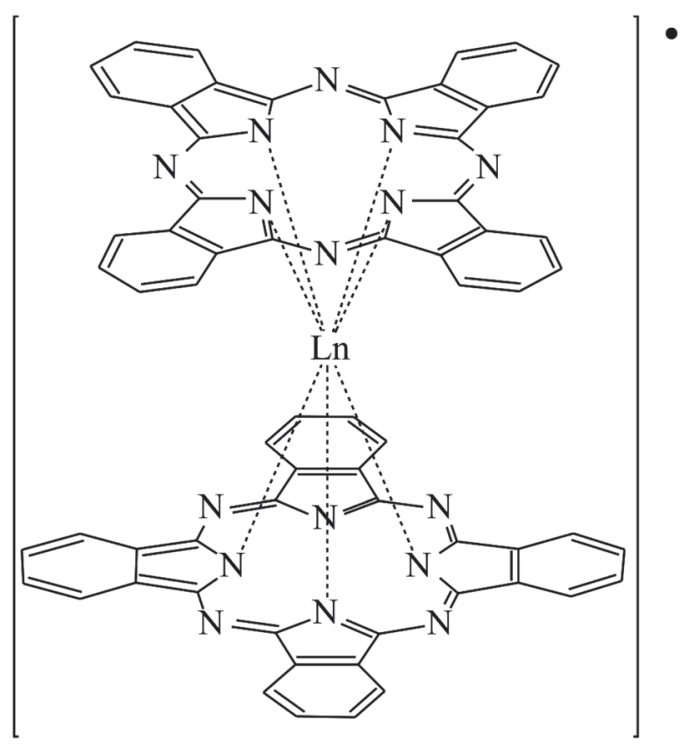

Figure 6. Structure of oxidized diphthalocyanines LnPc.

When sulfuric acid solutions of the complexes are kept at temperatures higher than $338 \mathrm{~K}$ (Sm, Eu, Gd) or 300 $\mathrm{K}(\mathrm{Pr}, \mathrm{Nd})$ a gradual decrease of $\mathrm{LnPc}_{2}{ }^{*}$ concentration is observed, there are no other colored forms in the solutions according to UV-vis spectra. Reprecipitation of the reaction mixture during the reaction process $\left(\tau_{1 / 2}\right)$ to ice gives the same result. The dissociation process is accompanied with rapid destruction of the macrocycle. Table $3 \mathrm{~S}$ shows values of effective rate constants, energy and entropy of dissociation activation of lanthanides diphthalocyanines in concentrated $\mathrm{H}_{2} \mathrm{SO}_{4}$. 
An order of diphthalocyanines $\mathrm{LnPc}_{2} \cdot$ dissociation on $\left[\mathrm{H}_{3} \mathrm{O}^{+}\right](n)$ changes when temperature changing and depends upon metal cation nature (Table 2). For the same complex $n$ value is smaller at the higher temperature. At $298 \mathrm{~K}$ the reaction order decreases in a series: $\mathrm{Eu}>\mathrm{Gd}>\mathrm{Sm}>\mathrm{Pr}, \mathrm{Nd}$, that is in a reverse succession compared with $\log k^{298}$ and $E$ values changing.

It can be supposed that the first order on $\mathrm{LnPc}_{2}{ }^{\bullet}$ and high variable order on $\mathrm{H}_{3} \mathrm{O}^{+}$are connected with the following elementary reactions:

$\mathrm{LnPc}_{2} \cdot+(n-2) \mathrm{H}_{3} \mathrm{O}^{+} \Leftrightarrow \operatorname{LnPc}_{2} \cdot \ldots(n-2) \mathrm{H}_{3} \mathrm{O}^{+}$

$\mathrm{LnPc}_{2} \cdot \ldots(n-2) \mathrm{H}_{3} \mathrm{O}^{+}+2 \mathrm{H}_{3} \mathrm{O}^{+} \rightarrow$

$\rightarrow\left[\left(\mathrm{H}_{2} \mathrm{O}\right)_{2} \mathrm{LnPc}\right]^{+}+\mathrm{H}_{2} \mathrm{Pc}^{\bullet} \ldots(n-2) \mathrm{H}_{3} \mathrm{O}^{+}$

$\left[\left(\mathrm{H}_{2} \mathrm{O}\right)_{2} \mathrm{LnPc}\right]^{+}+2 \mathrm{H}_{3} \mathrm{O}^{+} \rightarrow\left[\left(\mathrm{H}_{2} \mathrm{O}\right)_{4} \mathrm{Ln}\right]^{3+}+\mathrm{H}_{2} \mathrm{Pc}_{\mathrm{Solv}}$

$\mathrm{H}_{2} \mathrm{Pc}_{\text {Solv }} \rightarrow$ destruction products

The total process rate is limited by reaction (12). $\mathrm{LnPc}_{2}{ }^{\circ}$ transformation to mono-phthalocyanine complex (reactions 11,12 ) is a result of solvo-protolytical dissociation of $\mathrm{Ln}-\mathrm{N}$ bonds under the action of $\mathrm{H}_{3} \mathrm{O}^{+}$cations but not owing to splitting one of two macrocycles of $\mathrm{LnPc}_{2}$.

Like monophthalocyanine complexes dissociation in ethanol-AcOH mixtures, the rate of diphthalocianine complexes dissociation in sulfuric acid decreases in the lanthanides row. Gd complex is an exception. This is connected with peculiarities of structure of electron $f$-shells of the metal cation and essential covalence of the complexes.
When $\mathrm{LnPc}_{2}{ }^{\bullet}(\mathrm{Ln}=\mathrm{Pr}, \mathrm{Nd}, \mathrm{Sm})$ concentration in sulfuric acid solution growing from $2 \cdot 10^{-5}$ to $1 \cdot 10^{-4} \mathrm{~mol} / 1$ the UV-vis spectrum changes (Figure 7, compare curves 3 and 1). Absorption band of the diphthalocyanine $\operatorname{LnPc}_{2}{ }^{\bullet}(420 \mathrm{~nm})$ is shifted bathochromically and decreases in intensity with the complex concentration growth. High-energy absorption bands (838, $775 \mathrm{~nm}$ ) become more intensive. This spectrum is characteristic for dimer diphthalocyanine complexes ${ }^{[10,71]}$ which also undergo dissociation in concentrated acid solutions (Figure 7).

Tb, Dy, Ho, Er, Tm diphthalocyanines are stable in 16$18 \mathrm{M} \mathrm{H}_{2} \mathrm{SO}_{4}$ at $298 \mathrm{~K}$ and in $100 \% \mathrm{H}_{2} \mathrm{SO}_{4}$ even at $400 \mathrm{~K}$. In more diluted $\mathrm{H}_{2} \mathrm{SO}_{4}(12 \mathrm{M}) \mathrm{LnPc}_{2} \cdot$ dissolve with destruction. When heating the diphthalocyanine solutions in 16-18 M $\mathrm{H}_{2} \mathrm{SO}_{4}$ a progressive decrease of intensity of the visible absorption band is observed. Dissociation rate constants grow with temperature increasing and with lowering $\mathrm{H}_{2} \mathrm{SO}_{4}$ concentration (Table 4S). $\log k_{o b s}^{T}$ Values (Table 3) are proportional to $\log \left[\mathrm{H}_{3} \mathrm{O}^{+}\right]^{\mathrm{n}}$ values.

Data of Tables 2, 3 show that the reaction orders on $\left[\mathrm{H}_{3} \mathrm{O}^{+}\right](n)$ is higher 2 in the most cases and varies when varying metal nature. $n$ value is higher when higher $p k$ value of diphthalocyanine dissociation. State of Pr-Tm diphthalocyanines concentrated $\mathrm{H}_{2} \mathrm{SO}_{4}$ was studied by UVvis and NMR spectroscopy in order to determine the causes of increasing the dissociation reaction order. UV-vis spectra of lanthanides diphthalocyanines of $\mathrm{La}$ and $\mathrm{Y}$ sub-groups have large differences (Table 4).

Spectra of freshly prepared sulfuric acid solutions of diphthalocyanines of lanthanides of the first group contain intensive absorption bands at 700-900 nm (Figure 8). In several hours at the room temperature (or several minutes

Table 2. Kinetic characteristics of lanthanides diphthalocyanines in $17.7 \mathrm{M} \mathrm{H}_{2} \mathrm{SO}_{4}\left(n-\right.$ order on $\left.\left[\mathrm{H}_{3} \mathrm{O}^{+}\right]\right)$.

\begin{tabular}{|c|c|c|c|c|c|c|c|c|c|c|c|}
\hline \multirow{2}{*}{$\mathrm{T}, \mathrm{K}$} & $n$ & $-\log k$ & $n$ & $-\log k$ & $\mathrm{~T}, \mathrm{~K}$ & $n$ & $-\log k$ & $n$ & $-\log k$ & $n$ & $-\log k$ \\
\hline & \multicolumn{2}{|c|}{$\mathrm{NdPc}_{2} \cdot$} & \multicolumn{2}{|c|}{$\operatorname{PrPc}_{2}^{\cdot}$} & & \multicolumn{2}{|c|}{$\mathrm{SmPc}_{2}^{\cdot}$} & \multicolumn{2}{|c|}{$\mathrm{EuPc}_{2}^{\cdot}$} & \multicolumn{2}{|c|}{$\mathrm{GdPc}_{2}^{\bullet}$} \\
\hline 298 & 3.2 & 6.4 & 3.2 & 6.4 & 298 & 4.4 & 8.9 & 6.6 & 10.6 & 6.0 & 9.8 \\
\hline 308 & 1.95 & 5.15 & 2.0 & 5.2 & 338 & 3.6 & 7.2 & 2.7 & 6.2 & 2.8 & 6.2 \\
\hline \multirow[t]{2}{*}{318} & 1.4 & 4.2 & 1.4 & 4.2 & 348 & 3.3 & 6.7 & 2.9 & 6.15 & 2.7 & 5.8 \\
\hline & & & & & 358 & 3.7 & 6.9 & 2.4 & 5.4 & 2.07 & 4.9 \\
\hline
\end{tabular}

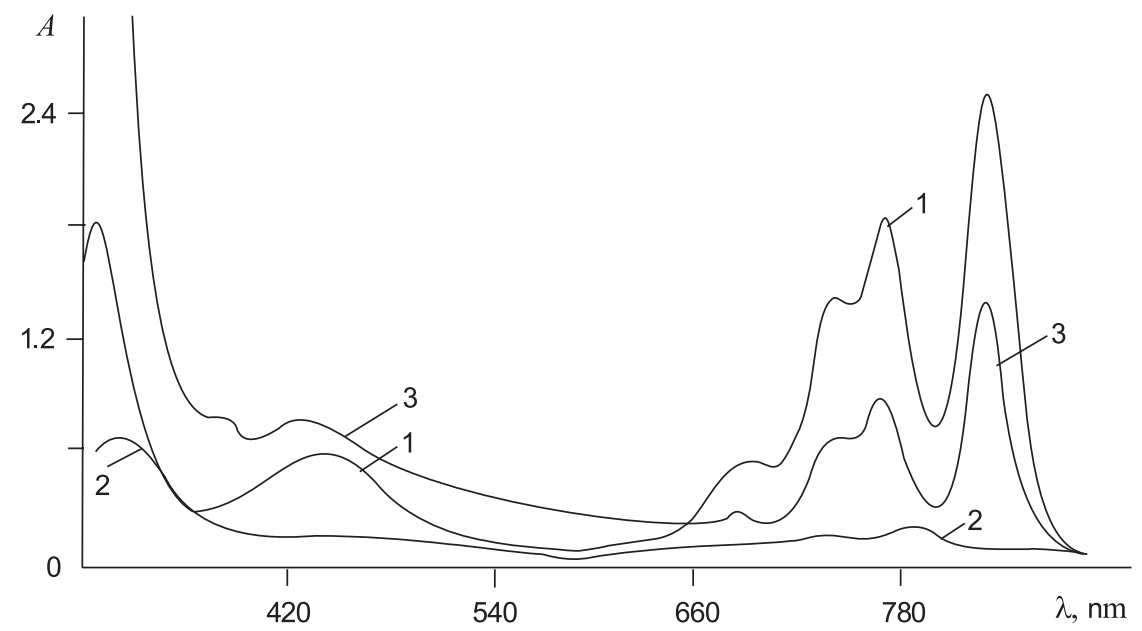

Figure 7. Electron absorption spectra of $\left[\mathrm{NdPc}_{2}{ }^{\circ}\right]$ in $17.7 \mathrm{M} \mathrm{H}_{2} \mathrm{SO}_{4}$ for $\left[\mathrm{NdPc}_{2}{ }^{\cdot}\right] \cong 1 \cdot 10^{-4}(1,2)$ and $2 \cdot 10^{-5}(3)$ mol/1 at $298 \mathrm{~K}$; time: 1 and $3-0 ; 2-24$ hours. 
Table 3. Reaction order on $\left[\mathrm{H}_{3} \mathrm{O}^{+}\right](n)$ and rate constants for $\mathrm{LnPc}_{2}{ }^{\cdot}$ dissociation reaction in concentrated $\mathrm{H}_{2} \mathrm{SO}_{4}$

\begin{tabular}{|c|c|c|c|}
\hline Diphthalocyanine & $\mathrm{T}, \mathrm{K}$ & $n$ & $-\log k$ \\
\hline \multirow[t]{3}{*}{$\mathrm{TbPc}_{2} \cdot$} & 338 & 4.1 & 7.6 \\
\hline & 348 & 5.4 & 9.0 \\
\hline & 358 & 4.5 & 7.8 \\
\hline \multirow[t]{3}{*}{$\mathrm{DyPc}_{2}{ }^{\circ}$} & 338 & 5.6 & 9.4 \\
\hline & 348 & 7.3 & 11.2 \\
\hline & 358 & 7.3 & 10.9 \\
\hline \multirow[t]{3}{*}{$\mathrm{HoPc}_{2}{ }^{\cdot}$} & 338 & 5.2 & 9.3 \\
\hline & 348 & 6.7 & 10.8 \\
\hline & 358 & 5.0 & 8.4 \\
\hline \multirow[t]{3}{*}{$\mathrm{ErPc}_{2}{ }^{\circ}$} & 338 & 2.2 & 6.4 \\
\hline & 348 & 5.9 & 10.1 \\
\hline & 358 & 6.6 & 10.5 \\
\hline \multirow[t]{3}{*}{$\mathrm{TmPc}_{2}{ }^{\bullet}$} & 338 & 4.3 & 9.3 \\
\hline & 348 & 4.6 & 9.4 \\
\hline & 358 & 5.7 & 10.2 \\
\hline
\end{tabular}

at $320 \mathrm{~K}$ ) the spectra of $\mathrm{Sm}, \mathrm{Eu}, \mathrm{Gd}$ complexes change and become analogous in character to spectra of complexes of lanthanides from $\mathrm{Tb}$ to $\mathrm{Lu}\left(\mathrm{LnPc}_{2}{ }^{\circ}\right)$ (Table 4).

Number of bands in spectra of Pr and $\mathrm{Nd}$ complexes does not change in time but the intensity of the absorption bands decreases because of the complex dissociation (Table $3 \mathrm{~S})$. The transformation of diphthalocyanine spectra in time is obviously connected with formation of dimers of diphthalocyanines in freshly prepared solutions. According to opinion of the author of ${ }^{[27]} \mathrm{LnPc}_{2}{ }^{\bullet}$ complexes exist as dimers in a solid state. The dimers transfer to monomeric diphthalocyanines $\mathrm{LnPc}_{2} \cdot$ when dissolving in concentrated $\mathrm{H}_{2} \mathrm{SO}_{4}$, which has high dielectric constant. This is the cause of the spectra changing in time or when heating. Spectral data (Table 4, Figure 8) show that the complexes of lanthanides of the second row half are less inclined to dimer formation what could be connected with their larger susceptibility to unpaired electron delocalization as compared with the complexes of La sub-group. Thus, in dissociation conditions the complexes exist as the monomeric sandwich molecules (radicals). Proton absence, i.e. $\mathrm{LnPc}_{2} \mathrm{H}$ particles absence is shown by ${ }^{1} \mathrm{H}$ NMR spectra investigations. Signals are not observed in $\mathrm{D}_{2} \mathrm{SO}_{4}$ solutions.

Table 4. Position $\left(\lambda_{\max }\right)$ and intensity (log $\varepsilon$ ) (in brackets) of adsorption bands in $\mathrm{LnPc}_{2} \cdot \mathrm{UV}$-vis spectra in $17.7 \mathrm{M} \mathrm{H}_{2} \mathrm{SO}_{4}$.

\begin{tabular}{|c|c|c|c|c|c|c|c|}
\hline \multirow{2}{*}{ Diphthalocyanine } & \multicolumn{7}{|c|}{$\lambda_{\max }$} \\
\hline & I & II & III & IV & $\mathrm{V}$ & VI & VII \\
\hline $\mathrm{PrPc}_{2}{ }^{\circ}$ & $837(5.16)$ & $775(5.02)$ & $745^{\mathrm{a}}$ & $690^{\mathrm{a}}$ & $443(4.51)$ & $305(4.90)$ & 250 \\
\hline $\mathrm{NdPc}_{2} \cdot$ & $837(5.11)$ & $775(4.96)$ & $745^{\mathrm{a}}$ & $690^{\mathrm{a}}$ & $442(4.47)$ & $305(4.85)$ & 250 \\
\hline $\mathrm{SmPc}_{2}{ }^{\cdot}$ & - & $783(3.26)$ & - & - & $410(4.32)$ & - & 250 \\
\hline $\mathrm{EuPc}_{2}{ }^{\cdot}$ & - & - & - & - & $410(4.00)$ & - & 250 \\
\hline $\mathrm{GdPc}_{2} \cdot$ & - & - & - & - & $407(4.00)$ & $315^{\mathrm{a}}$ & 250 \\
\hline $\mathrm{TbPc}_{2} \cdot$ & - & - & - & - & $397(4.43)$ & $285(4.78)$ & 250 \\
\hline $\mathrm{LuPc}_{2}{ }^{-}$ & - & - & - & - & $395(4.60)$ & $285(4.83)$ & $253(4.99)$ \\
\hline
\end{tabular}

${ }^{a}$ shoulder

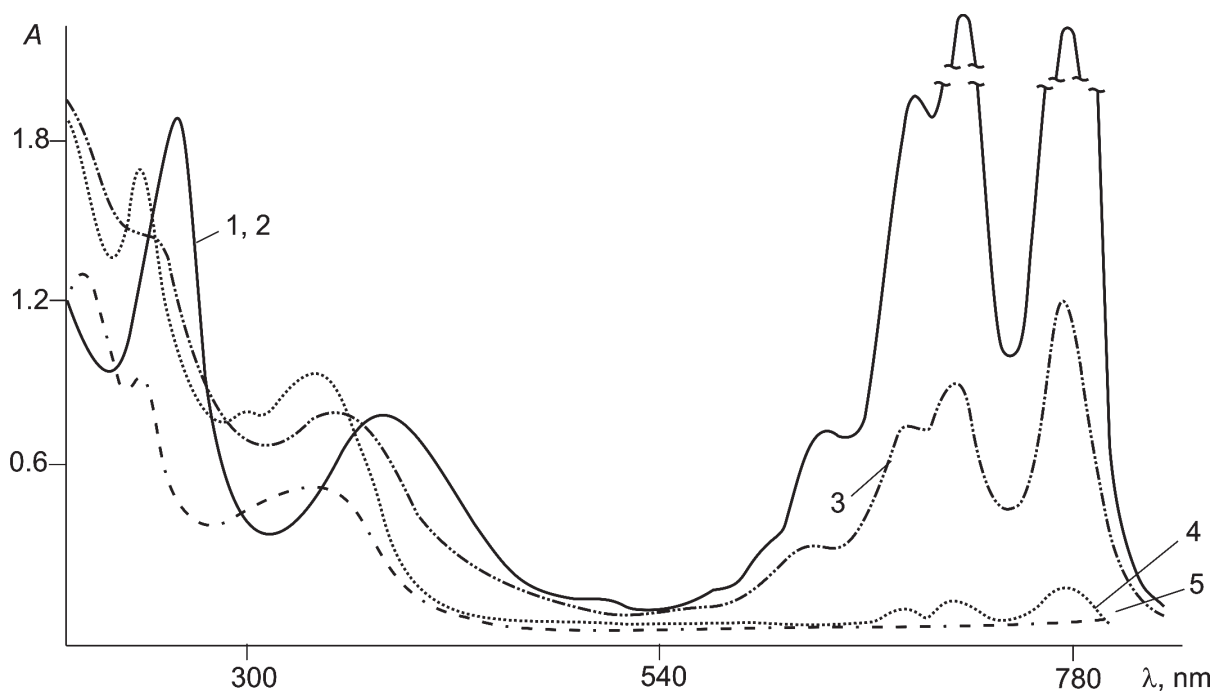

Figure 8. Electron absorption spectra of freshly prepared solutions of diphthalocyanines in $17.2 \mathrm{M} \mathrm{H}_{2} \mathrm{SO}_{4} .1-\mathrm{Pr}, 2-\mathrm{Nd}, 3-\mathrm{Sm}, 4-\mathrm{Ho}$, $5-\mathrm{Yb} .\left[\mathrm{LnPc}_{2}{ }^{\circ}\right]=2 \cdot 10^{-5} \mathrm{~mol} / 1$. 
Non-constant order on $\left[\mathrm{H}_{3} \mathrm{O}^{+}\right]$of reaction (12) does not allow using $p k^{298}$ value for comparative estimation of the complex stability. Because of this, the $p k_{o b s}^{298}$ values for the same $\mathrm{H}_{2} \mathrm{SO}_{4}$ concentration for different complexes are shown in Figure 9.

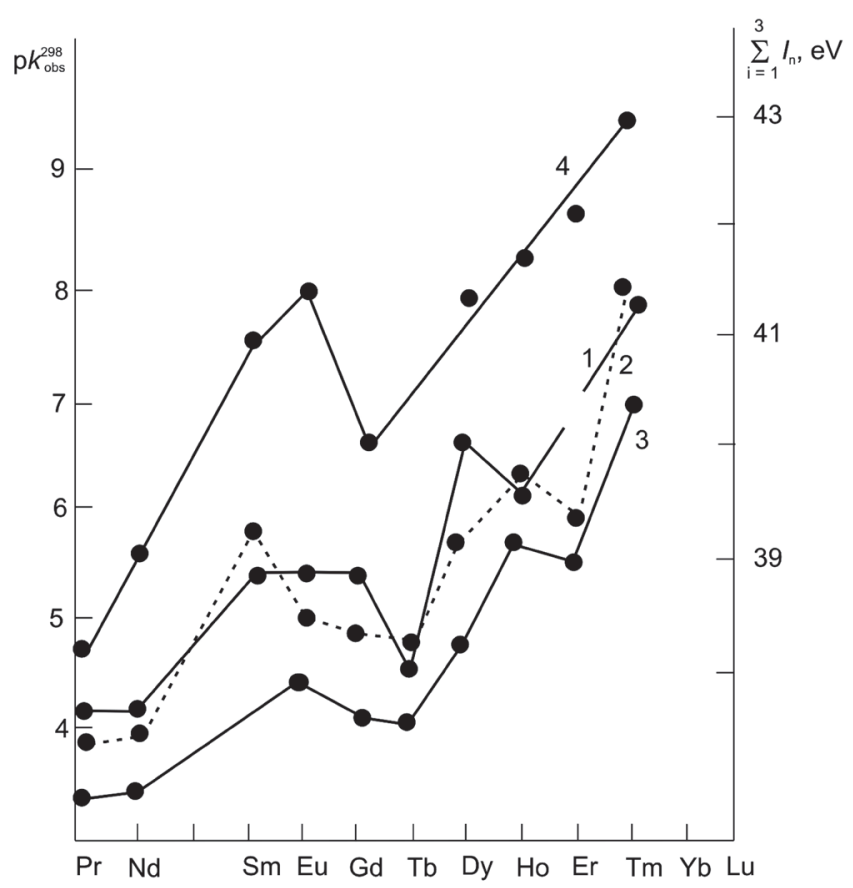

Figure 9. Dependence of $p k_{o b s}^{298}$ for $\mathrm{LnPc}_{2}$ dissociation in $\mathrm{H}_{2} \mathrm{SO}_{4}$ (1-3) and summarizes the third potential of ionization of rare earth metals (4) on lanthanides number. $\left[\mathrm{H}_{2} \mathrm{SO}_{4}\right], \mathrm{mol} / \mathrm{l}: 17.7$ (1), 16.9 (2), 15.9 (3).
The character of $p k_{o b s}^{298}-Z$ dependence is the same as ionization potential changing in the lanthanides row (Figure 9). A deep minimum for Gd and Tb complexes is observed in all the investigated media. Eu complex is kinetically more stable than neighboring $\mathrm{GdPc}_{2}{ }^{\circ}$. Thus it could be concluded that, firstly, lanthanides diphthalocyanines must be regarded to covalent complexes and, secondly, that $f$-orbitals of metal take part in covalent Ln-N interaction. Complex of $\mathrm{Gd}\left(f^{\prime}\right)$ is essentially less stable than $\mathrm{EuPc}_{2}$ in which one electron is needed to addition of metal $f$-orbital to stable $f^{\prime}$ state. The last apparently promotes an electron density transfer from macrocycle $\pi$-orbitals to metal (dative $\pi$-bond $\mathrm{N} \rightarrow \operatorname{Ln}$ ). It ought to point out that "tetrade effect" found for dissociation of sulfur derivatives of lanthanide phthalocyanines in acid aqueous media ${ }^{[27]}$ is not corroborated by the data presented here.

Substituted double-decker lanthanide phthalocyanines are recently in increasing interest owing to their possibility to possess the intensive absorption and $4 f$ luminescence in near-infrared range. ${ }^{[72,73]}$

\section{Triple-Decker Metallophthalocyanines}

Maximum $\mathrm{Ln}_{2} \mathrm{Pc}_{3}$ yield is achieved in the reaction of $o$-phthalonitrile with a rare earth metal chloride in 6:1 mole ratio at $563 \mathrm{~K}$ during 1 hour (Experimental, ${ }^{[74]}$ ). The reaction mixture was cooled, dissolved in DMF and undergone preparative chromatography procedure on $\mathrm{Al}_{2} \mathrm{O}_{3}$. Two well divided zones of green and blue colors were observed. Every product has individual UV-vis and IR spectra. Green zone consists of sandwich structures $\mathrm{LnPc}_{2} \mathrm{H}$ (Figure 10a) described $\mathrm{in}^{[9]}$. Compounds of blue zone are triple-decker metallophthalocyanines (Figure 10b). Each of two metal

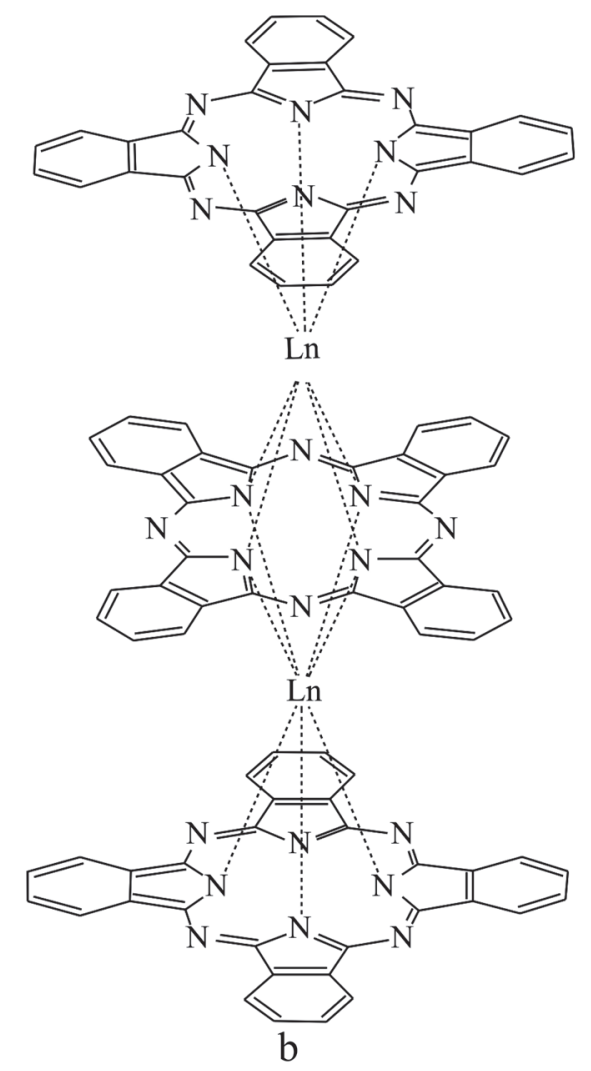

Figure 10. Structure of $\mathrm{H}$-containing diphthalocyanines $\mathrm{LnPc}_{2} \mathrm{H}$ (a) and triple-decker metallophthalocyanines $\operatorname{Ln}_{2} \mathrm{Pc}_{3}(\mathrm{~b})$. 
atoms is covalently bound with two macrocycles. Two equivalent each other external macrocycles are not adequate to the third, central macrocycle. This structure is confirmed by all the obtained experimental data described below.

As a whole data about triple-decker phthalocyanine complexes structure are not numerous. There are structural data on $\operatorname{In}_{2}(\mathrm{Pc})_{3},{ }^{[75]}$ Lu complex with tetra-15-crown5-phthalocyanine ${ }^{[18]}$ and few heteroleptic porphyrin/ phthalocyanine complexes. ${ }^{[76]}$ The first structure reported for a heteroleptic triple-decker crown-phthalocyaninato complex was represented in the work ${ }^{[77]}$ on an example of a complex $(\mathrm{Pc}) \operatorname{Sm}\left[(15 \mathrm{C} 5)_{4} \mathrm{Pc}\right] \mathrm{Sm}(\mathrm{Pc})$. The central ligand in $\mathrm{Lu}$ complex is turned to $43.7^{0}$ about external ligands. Average distance between macrocycle planes is $2.923 \AA$. Lu atoms are localized between the ligands. Average distances between $\mathrm{Lu}$ atoms and coordinating $\mathrm{N}$ atoms of external ligands are equal $2.305 \AA$. Analogous distances to the central ligand $\mathrm{N}$ atoms are much larger $(2.560 \AA)$ ). According to the $\mathrm{X}$-ray data, ${ }^{[77]}(\mathrm{Pc}) \mathrm{Sm}\left[(15 \mathrm{C} 5)_{4} \mathrm{Pc}\right] \mathrm{Sm}(\mathrm{Pc})$ has a symmetrical structure with two $\mathrm{Sm}$ atoms located at a nonbonding $\mathrm{Sm}-\mathrm{Sm}$ distance of 3.5111(4) $\AA$. The distances between the samarium and nitrogen atoms are determined as 2.613(3) and 2.599(3) $\AA$ for the central bridging crown-substituted macrocycle and as 2.372(3), 2.385(3), 2.397(3) and 2.395(3) $\AA$ for the outer Pc ligands. The average twist angle of distorted square antiprisms is equal to $43^{\circ}$.

${ }^{13} \mathrm{C}$ NMR spectrum shows more than 4 signals of carbon, ${ }^{[78]}$ i.e. there are macrocycles of two types in the

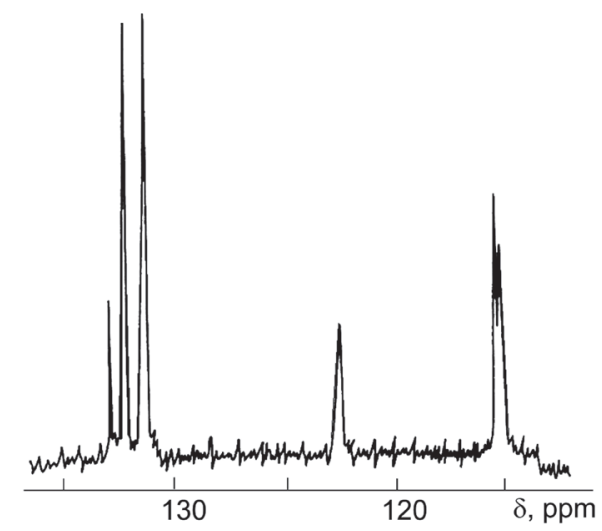

Figure 11. ${ }^{13} \mathrm{C}$ NMR (b) spectra of $\mathrm{Tm}_{2} \mathrm{Pc}_{3}$ in $\mathrm{CDCl}_{3}$. Bruker AM500, 125.7 MHz. sample (one central and two equal each other external macrocycles) (Figure 11).

$\mathrm{UV}$-vis spectra of complexes $\mathrm{LnPc}_{2} \mathrm{H}$ and $\mathrm{Ln}_{2} \mathrm{Pc}_{3}$ differ from those of (X)LnPc (Figure 12). Typical UV-vis spectrum of metal phthalocyanine in organic solvent has long-wave maximum in the region $670-700 \mathrm{~nm}\left(\pi \rightarrow \pi^{*}\right.$ transition, ${ }^{[79]} \mathrm{Q}$ band) and its oscillation component of lower intensity about $610 \mathrm{~nm}$. Intensive Soret band is disposed at 330-390 nm (B band). In the lanthanides raw the UV-vis spectra show low dependence from Ln and acido-ligand nature (Table 1). This differs the complexes with 1:1 composition from doubleand triple-deckers (Table 4, ${ }^{[80,81]}$ ). Both $\mathrm{LnPc}_{2} \mathrm{H}$ and $\mathrm{Ln}_{2} \mathrm{Pc}_{3}$ exhibit typical features of the electronic absorption spectra for rare earth double- and triple-decker complexes with the new low-intensity absorption appearing at $c a .420 \mathrm{~nm}$ and hypsochromically shifted Q band at $c a .660 \mathrm{~nm}$. The band observed in near IR at $c a .870 \mathrm{~nm}$ in such neutral solvent as benzene is also attributed to the double- and tripledecker complex absorption not only for oxidized doubledecker $\mathrm{LnPc}_{2}$ bat for neutral $\mathrm{LnPc}_{2} \mathrm{H}^{[82]}$ and triple-decker $\mathrm{Ln}_{2}\left(\mathrm{PcR}_{4}\right) \mathrm{P}_{2}(\mathrm{R}=$ dinaphto[1,2-e:1',2'-g]-1,4-dioxocine group, $\mathrm{P}=5,10,15,20$-tetrakis(4-chlorophenyl)porphyrin dianion). ${ }^{[76]}$ ZINDO calculations of molecules, cations and anions of simpl ZnPc using 16-orbital model and data of magnetic circular dichroism ${ }^{[83,84]}$ show that highly symmetric $\mathrm{ZnPc}$ demonstrates the orbital degenerated main state: two boundary HOMO are degenerated. When the removal of one electron, on the example of the transition from $\mathrm{ZnPc}$ to the $\mathrm{ZnPc}^{+}$, takes place, the similar degeneracy lifting and the appearance of new bands of $\pi \rightarrow \pi$ transition within the occupied shells ( $\pi^{*} \rightarrow \pi^{*}$ transition in the case of $\left.\mathrm{ZnPc}^{-}\right)$together with bathochromic shifted Q bands at 958 and 925 $\mathrm{nm}$, a band of second $\pi \rightarrow \pi^{*}$ transition at 300-450 nm and $\mathrm{B}_{1}, \mathrm{~B}_{2}$ and $\mathrm{n} \rightarrow \pi^{*}$ bands are observed. Assumption of two equilibrium redox $\left(\mathrm{LnPc}_{2} / \mathrm{LnPc}_{2} \mathrm{H}\right)$ or acid-base $\left(\mathrm{LnPc}_{2}{ }^{-} /\right.$ $\mathrm{LnPc}_{2} \mathrm{H}$ ) form in benzene solution of considered $\mathrm{LnPc}_{2} \mathrm{H}$ is not confirmed due to experimental data. A view of spectra 2 and 3 in Figure 12 at $c a .420$ and $870 \mathrm{~nm}$ stays same after treatment of benzene solution by means of DMF-hydrazine hydrate or $\mathrm{HCl}$.

IR-spectra of the obtained compounds correspond to metallophthalocyanines spectra. ${ }^{[85]}$ There are differences in IR spectra of $\mathrm{TmPc}_{2} \mathrm{H}$ and $\mathrm{Tm}_{2} \mathrm{Pc}_{3}$ in the region of $\mathrm{v}(\mathrm{CH})$ benzene rings vibrations: $v(\mathrm{CH})=2816,2920,2984$, $3080 \mathrm{~cm}^{-1}$ for $\mathrm{TmPc}_{2} \mathrm{H}$ and 2784, 2800, 2968, 3010, 3040,

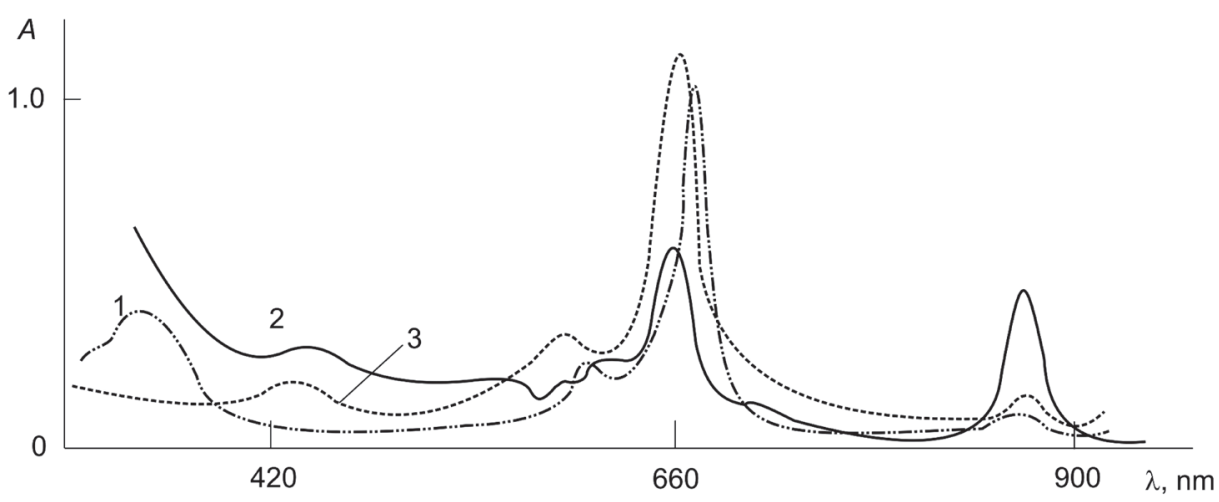

Figure 12. UV-vis spectra of $(\mathrm{X}) \mathrm{TmPc}(1), \mathrm{TmPc}_{2} \mathrm{H}(2)$ and $\mathrm{Tm}_{2} \mathrm{Pc}_{3}(3)$ in benzene. 
Table 5. Kinetic parameters of dissociation of $\mathrm{LnPc}_{2} \mathrm{H}$ complexes forming during $\mathrm{Ln}_{2} \mathrm{Pc}_{3}$ dissolving in $15.9 \mathrm{M} \mathrm{H}_{2} \mathrm{SO}_{4}$.

\begin{tabular}{|c|c|c|c|c|c|}
\hline \multirow{2}{*}{ Complex } & \multicolumn{3}{|c|}{$k_{o b s}^{298 K} \cdot 10^{3}, \mathrm{~s}^{-1}$} & \multirow{2}{*}{$\begin{array}{c}E, \\
\mathrm{~kJ} / \mathrm{mol}\end{array}$} & \multirow{2}{*}{$\begin{array}{c}\Delta S^{\ddagger}, \\
\mathrm{J} / \mathrm{mol} \mathrm{K}\end{array}$} \\
\hline & $338 \mathrm{~K}$ & $348 \mathrm{~K}$ & $358 \mathrm{~K}$ & & \\
\hline $\mathrm{Sm}_{2} \mathrm{Pc}_{3}$ & $0.73 \pm 0.02$ & $1.60 \pm 0.08$ & $2.6 \pm 0.1$ & $63 \pm 13$ & $-125 \pm 39$ \\
\hline $\mathrm{Gd}_{2} \mathrm{Pc}_{3}$ & $0.88 \pm 0.09$ & $1.7 \pm 0.1$ & $2.80 \pm 0.09$ & $58 \pm 8$ & $-140 \pm 22$ \\
\hline
\end{tabular}

Table 6. Kinetic parameters of dissociation of $\mathrm{Th}_{2} \mathrm{TPP}_{3}$ in ethanol-acetic acid solvents.

\begin{tabular}{|c|c|c|c|c|c|c|}
\hline \multirow{2}{*}{$\mathrm{C}^{0}{ }_{\mathrm{AcOH}}, \%$} & \multicolumn{4}{|c|}{$k_{o b s} \cdot 10^{3}, \mathrm{~s}^{-1}$} & \multirow{2}{*}{$\begin{array}{c}E, \\
\mathrm{~kJ} / \mathrm{mol}\end{array}$} & \multirow{2}{*}{$\begin{array}{c}\Delta S^{\neq}, \\
\mathrm{J} / \mathrm{mol} \cdot \mathrm{K}\end{array}$} \\
\hline & $298 \mathrm{~K}$ & $333 \mathrm{~K}$ & $343 \mathrm{~K}$ & $353 \mathrm{~K}$ & & \\
\hline 60 & $0.80 \pm 0.02$ & $1.64 \pm 0.02$ & $1.95 \pm 0.02$ & $2.32 \pm 0.02$ & $16.6 \pm 0.5$ & $-256 \pm 2$ \\
\hline 50 & $0.50 \pm 0.02$ & $0.996 \pm 0.03$ & $1.17 \pm 0.02$ & $1.39 \pm 0.04$ & $16.2 \pm 0.8$ & $-262 \pm 3$ \\
\hline 40 & $0.31 \pm 0.01$ & $0.60 \pm 0.01$ & $0.70 \pm 0.01$ & $0.83 \pm 0.01$ & $15.5 \pm 0.9$ & $-268 \pm 3$ \\
\hline
\end{tabular}

$3080 \mathrm{~cm}^{-1}$ for $\mathrm{Tm}_{2} \mathrm{Pc}_{3}$. IR-spectrum of triple-decker $\mathrm{Tm}_{2} \mathrm{Pc}_{3}$ contains larger number of bands than $\mathrm{TmPc}_{2} \mathrm{H}$ spectrum. This could be connected with the presence of one more phthalocyanine ligand.

Triple-deckers $\mathrm{Ln}_{2} \mathrm{Pc}_{3}$ dissociate in the mixed ethanol$\mathrm{H}_{2} \mathrm{SO}_{4}(20: 1)$ solvent at $298 \mathrm{~K}$ giving double-deckers $\mathrm{LnPc}_{2} \mathrm{H}$ and $\mathrm{H}_{2} \mathrm{Pc}$. The last is insoluble in the experimental conditions and falls to sediment blue-green in color during several hours. Low stability of $\mathrm{Ln}_{2} \mathrm{Pc}_{3}$ complexes in comparison with $\mathrm{LnPc}_{2}{ }^{\cdot}$ is obviously connected with mutual pushing off the macrocycles in the coordination sphere of the tripledecker complexes.

Rates of $\mathrm{Ln}_{2} \mathrm{Pc}_{3}$ dissociation in $\mathrm{H}_{2} \mathrm{SO}_{4}$ are equal to the rates of the corresponding $\mathrm{LnPc}_{2} \mathrm{H}$ complexes dissociation. Observed kinetic parameters for dissociation of $\mathrm{LnPc}_{2} \mathrm{H}$ complexes forming during $\mathrm{Ln}_{2} \mathrm{Pc}_{3}$ dissolving (Table 5) are close to the values ${ }^{[59]}$ obtained for $\mathrm{LnPc}_{2} \mathrm{H}$ synthesized according to traditional method..$^{[9,58]}$

$\mathrm{Ln}_{2} \mathrm{Pc}_{3}$ complexes are not dissolved in water or undergo dissociation in it. They are weakly dissolved in the coordinating solvents. Thus the initial complex is not ionic compound as authors of works ${ }^{[9,58,86,87]}$ suppose. Analogous conditions of dissociation (ethanol- $\mathrm{H}_{2} \mathrm{SO}_{4}$ mixtures) of $\mathrm{Ln}_{2} \mathrm{Pc}_{3}$ complexes (to $\mathrm{LnPc}_{2} \mathrm{H}$ and $\mathrm{H}_{2} \mathrm{Pc}$ ) and their monophthalocyanine (X)LnPc analogs (to $\mathrm{Ln}^{3+}, \mathrm{X}^{-}$and $\mathrm{H}_{2} \mathrm{Pc}$ ) is one more evidence of the covalent nature of donor-acceptor bonds in $\mathrm{Ln}_{2} \mathrm{Pc}_{3}$.

\section{Double- and Triple-Decker Actinide Porphyrins}

$\mathrm{U}^{\mathrm{IV}}$ and $\mathrm{Th}^{\mathrm{IV}}$ double-decker complexes were obtained by reaction of $\mathrm{H}_{2}$ TPP or $\mathrm{H}_{2}$ OEP with diethyl amide metal complexes. ${ }^{[19,88,89]}$ Triple-decker thorium(III) tetraphenylporphyrin with structure analogous to $\mathrm{Ln}_{2} \mathrm{Pc}_{3}$ (Figure 10b) was obtained for the first time by the authors of the present work in 1991. ${ }^{[90]}$

The coordination geometry of $\mathrm{Th}(\mathrm{TPP})_{2}$ is a distorted square-antiprism where the thorium center is displaced by $1.47 \AA$ from each of the porphyrin $\mathrm{N}_{4}$ planes; the porphyrin $\mathrm{N}_{4}$ planes are therefore separated by $2.94 \AA \mathrm{A}^{\left[{ }^{[1]}\right.}$ In analogous octaethylporphyrin complex $\mathrm{Th}(\mathrm{OEP})_{2}$ the two porphyrin planes are separated by $2.89 \AA$ in a nearly perfect squareantiprismatic coordination geometry around the thorium center. The porphyrin macrocycles, held in such close proximity, interact electronically as shown by a blue shift in the porphyrin Soret band and by unusually low oxidation potentials relative to related monoporphyrin species. ${ }^{[91]}$

Thorium(IV) complexes $\mathrm{Th}^{\mathrm{IV}}(\mathrm{TPP})_{2}$ and $\mathrm{Th}_{2}^{\mathrm{III}}{ }_{2}(\mathrm{TPP})_{3}$ differ in solubility, UV-vis spectra (Figure 13) and reactivity with acids (Table 6). ${ }^{[90]} \mathrm{Th}(\mathrm{TPP})_{2}$ is soluble in ethanol whereas triple-decker complex $\mathrm{Th}_{2}(\mathrm{TPP})_{3}$ is unsoluble in one. UV-vis spectra of both complexes have specific features compared to spectra of (X)ThTPP. There is an additional intensive band at $426 \mathrm{~nm}$ in Th(TPP) ${ }_{2}$ spectrum and a wide band at $699 \mathrm{~nm}$ with low intensity in $\mathrm{Th}_{2}(\mathrm{TPP})_{3}$ spectrum. The Soret bands in both spectra are bathochromically shifted and split in two with $\lambda_{\max }$ equal 411 and $398 \mathrm{~nm}$. Visible absorption bands in Th(TPP) $)_{2}$ spectrum are bathochromically shifted as compared to those of $\mathrm{Th}_{2}(\mathrm{TPP})_{3}$. Analogous regularities is observed for $\mathrm{Ce}(\mathrm{OEP})_{2}$ and $\mathrm{Ce}_{2}(\mathrm{OEP})_{3}$ complexes. ${ }^{[79]}$ Appearance of wide absorption bands in the region higher than $650 \mathrm{~nm}$ in spectra of metalloporphyrins with two and more macrocycles the authors of ${ }^{[92]}$ explain by resonance interaction of the porphyrin ligands.

$\mathrm{Th}(\mathrm{TPP})_{2}$ dissociates in ethanol-AcOH as well as in benzene-AcOH solutions with acid content 50-90 vol. \%. $\mathrm{Th}_{2}(\mathrm{TPP})_{3}$ dissociates with measurable rate in the same mixtures with lesser acid content (25-60 vol. \%) (Table 6). Like in the case of $\mathrm{Ln}_{2} \mathrm{Pc}_{3}$ the triple-decker Th complex is less stable compared with Th(TPP) $)_{2}$.

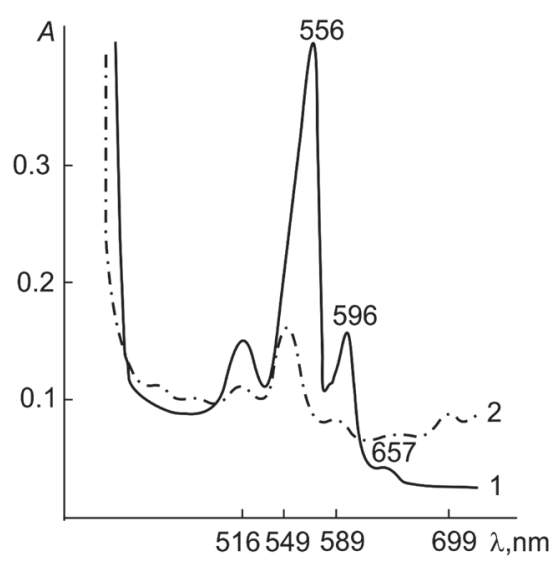

Figure 13. UV-vis spectra of Th(TPP) in ethanol (1) and $\mathrm{Th}_{2}(\mathrm{TPP})_{3}$ in benzene (2). 
Triple-decker uranium complex with tetraphenylporphyrin $\left(\mathrm{H}_{2} \mathrm{TPP}\right)$ was synthesized and studied for the first time in the laboratory of the authors in 2003. ${ }^{[93]}$ The reaction between $\mathrm{H}_{2} \mathrm{TPP}$ and $\mathrm{UO}_{2}(\mathrm{OAc})_{2}$ in molar ratio 1:10 in a refluxing benzonitrile medium during 19 hours yields two complexes U(TPP) ${ }_{2}$ and $\mathrm{U}_{2}(\mathrm{TPP})_{3}$. The complexes can be isolated by thin layer chromatography $\left(\mathrm{Al}_{2} \mathrm{O}_{3}\right)$ using benzene-chloroform (1:4) mixture. Individual complexes can be obtained also after the reaction mixture dissolving in ethanol after liquid chromatography on an $\mathrm{Al}_{2} \mathrm{O}_{3}$ column with $\mathrm{CHCl}_{3}$. Complex U(TPP) $)_{2}$ is soluble in ethanol whereas $\mathrm{U}_{2}(\mathrm{TPP})_{3}$ complex stays in a solid phase. Filtration gives a green-violet solid residue of $\mathrm{U}_{2}(\mathrm{TPP})_{3}$ (18\% yield). After ethanol evaporation from the filtrate a pink-violet powder of $\mathrm{U}(\mathrm{TPP})_{2}$ is obtained (14\% yield).

$\mathrm{U}^{\mathrm{IV}}(\mathrm{TPP})_{2}$ and $\mathrm{U}_{2}^{\mathrm{III}}(\mathrm{TPP})_{3}$ are stable in air and have spectral and chemical properties which are in agreement with a $1: 2$ and $2: 3$ uranium/tetraphenylporphyrin ratios. An analogous synthetic procedure in phenol gives double- and triple-decker uranium tetraphenylporphyrins mixture in 3 hours and 40 minutes.

The NMR spectrum of the double-decker complex agrees with the literature data for $\mathrm{Th}^{\mathrm{IV}}(\mathrm{TPP})_{2}{ }^{[88]}$ and $\mathrm{Ce}^{\mathrm{IV}}(\mathrm{TTP})$, (TTP - tetratolylporphyrin dianion). ${ }^{\left[{ }^{94]}\right.}$ The NMR spectrum of the triple-decker complex shows ten peaks what is in accord with ten kinds of protons: two $-\mathrm{C}_{4} \mathrm{H}_{2} \mathrm{~N}$ (one inner and two outer macrocycles), two $-p-\mathrm{C}_{6} \mathrm{H}_{5}$, three $o-\mathrm{C}_{6} \mathrm{H}_{5}$, and three $-m-\mathrm{C}_{6} \mathrm{H}_{5}$

Double-decker and triple-decker complexes have different UV-vis and IR spectra. The IR spectra of doubleand triple-decker complexes are more complicated in regions 700 ( $\gamma \mathrm{C}$-H of benzene rings), 800 ( $\gamma \mathrm{C}$-H of pyrrole rings), 990-1010 ( $\delta \mathrm{C}-\mathrm{H}, \vee \mathrm{C}-\mathrm{C}, \vee \mathrm{C}-\mathrm{N}$ of pyrrole rings), 1540$1550 \mathrm{~cm}^{-1}$ (pyrrole ring stretching) than these of lanthanide monoporphyrinates (X) $\mathrm{Ln}^{\text {III TPP. }}{ }^{[95]}$ The frequencies of vibrations $v(\mathrm{U}-\mathrm{N})\left(430\right.$ and $436 \mathrm{~cm}^{-1}$ for $\mathrm{U}^{\mathrm{IV}}(\mathrm{TPP})$, and $\mathrm{U}_{2}{ }_{2}(\mathrm{TPP})_{3}$ respectively) are higher than $v(\mathrm{Ln}-\mathrm{N})(\mathrm{Ln}: \mathrm{Sm}-$ $\left.\mathrm{Lu}, 421-429 \mathrm{~cm}^{-1}\right)$, which is connected with growth of the strength constant of U-N bond in the complexes of doubleand triple-decker structures. There are no bands at 212-216 $\mathrm{cm}^{-1}(\mathrm{v}(\mathrm{M}-\mathrm{Cl}),(\mathrm{M}-\mathrm{O}))$ in $\mathrm{U}^{\mathrm{IV}}(\mathrm{TPP})_{2}$ and $\mathrm{U}_{2}^{\mathrm{III}}(\mathrm{TPP})_{3}$ spectra because of the absence of acido ligands $\mathrm{X}^{-}\left(\mathrm{Cl}^{-}\right.$or $\left.\mathrm{C}_{6} \mathrm{H}_{5} \mathrm{O}^{-}\right)$in the complexes.

UV-vis spectra of both uranium complexes have specific features (Figures 14, 15). There are additional wide band at $657.9 \mathrm{~nm}$ of low intensity and an intensive band at 462 $\mathrm{nm}$ in $\mathrm{U}^{\mathrm{III}}{ }_{2}(\mathrm{TPP})_{3}$ spectrum as compared with $(\mathrm{X}) \mathrm{Ln}^{\mathrm{III}} \mathrm{TPP}$ spectra. An extra band at $462 \mathrm{~nm}$ may be due to a porphyrinto-uranium(III) charge-transfer transition. This could be connected with striving of the two uranium atoms with a coordination number of 8 for stable $f^{4}\left(\mathrm{a}_{2 u}{ }^{1} \mathrm{t}_{1 \mathrm{u}}{ }^{3}\right)$ configuration in the complex.

The double-decker $\mathrm{U}^{\mathrm{IV}}(\mathrm{TPP})_{2}$ complex has a "normal" metalloporphyrin UV-vis spectrum. Absorption bands in the visible region $\mathrm{Q}(0,0)$ are bathochromically shifted as compared to those of (X)Ln ${ }^{\mathrm{III}} \mathrm{TPP}$. For example for $(\mathrm{Cl})$ Lu ${ }^{\mathrm{III}} \mathrm{TPP}, \lambda_{\text {max }}(\log \varepsilon)$ are 585(3.5), 547(4.0), 510(3.6), 416(5.5) $\mathrm{nm}$ in ethanol. ${ }^{[95]}$ No band is found between 450 and 500 $\mathrm{nm}$ in $\mathrm{U}^{\mathrm{IV}}(\mathrm{TPP})_{2}$ spectrum. Analogous regularities were observed for $\mathrm{Ce}^{\mathrm{IV}}(\mathrm{OEP})_{2}$ and $\mathrm{Ce}^{\mathrm{III}}(\mathrm{OEP})_{3}$ complexes for which the crystal structure determination was described. ${ }^{[80]}$

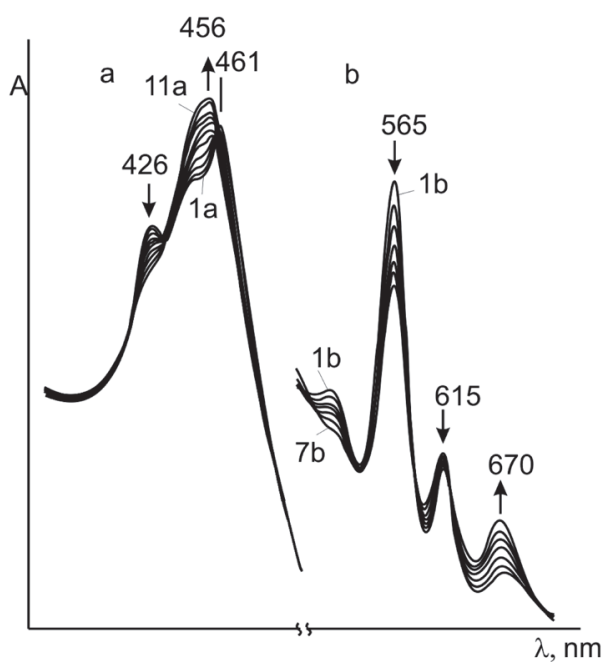

Figure 14. UV-vis spectra during dissociation of $\mathrm{U}^{\mathrm{III}}{ }_{2}(\mathrm{TPP})_{3}$ (a) in benzene $-40(\%) \mathrm{AcOH}, 308 \mathrm{~K}, 0-1$ hour and $\mathrm{U}^{\mathrm{IV}}(\mathrm{TPP})_{2}(\mathrm{~b})$, in ethanol - $55(\%) \mathrm{AcOH}, 353 \mathrm{~K}, 0$ - 4 hours. Curve 1a corresponds to $\mathrm{U}_{2}^{\mathrm{III}}(\mathrm{TPP})_{3}, 1 \mathrm{~b}-\mathrm{U}^{\mathrm{IV}}(\mathrm{TPP})_{2}, 11 \mathrm{a}-\mathrm{U}^{\mathrm{IV}}(\mathrm{TPP})_{2}+\mathrm{H}_{4} \mathrm{TPP}^{2+}, 7 \mathrm{~b}-$ $(\mathrm{AcO})_{2} \mathrm{U}^{\mathrm{IV}} \mathrm{TPP}+\mathrm{H}_{4} \mathrm{TPP}^{2+}$.

Appearance of wide absorption bands in the region higher $650 \mathrm{~nm}$ in the spectra of metalloporphyrins with two and more macrocycles was explained ${ }^{[92]}$ by resonance interaction of the porphyrin ligands. The corresponding broad bands in the double-decker complex $\mathrm{U}^{\mathrm{IV}}(\mathrm{TPP})_{2}$ is between 950 and $1000 \mathrm{~nm}$.

Chemical properties of double- and triple-decker porphyrin complexes are essentially different. The complexes $\mathrm{U}^{\mathrm{IV}}(\mathrm{TPP})_{2}$ and $\mathrm{U}_{2}^{\mathrm{III}}(\mathrm{TPP})_{3}$ dissociate with a spectrophotometrically measured rate only in the presence of $\mathrm{AcOH}$ in concentrations higher $40 \%$. $\mathrm{U}^{\mathrm{IV}}(\mathrm{TPP})_{2}$ dissociates in mixed ethanol-AcOH solvent at 330-350 K, whereas $\mathrm{U}_{2}^{\mathrm{III}}(\mathrm{TPP})_{3}$ dissociates in benzene-AcOH media and $300-320 \mathrm{~K}$. The dissociation rate constants of formally the first order $\left(k_{o b s}^{298 K}\right)$ at a $50 \% \mathrm{AcOH}$ concentration in the mentioned solvents are equal $10^{-4}$ and $0.5 \cdot 10^{-3} \mathrm{~s}^{-1}$ for U(TPP) and $\mathrm{U}_{2}(\mathrm{TPP})_{3}$, respectively. Taking in to account that the reactivity of the complexes changes greatly when changing from one mixed solvent to another, ${ }^{\left[{ }^{[6]}\right]}$ it is possible to note an enormous difference in stability of the double- and tripledecker complexes. The UV-vis absorption spectra of $\mathrm{U}^{\mathrm{IV}}(\mathrm{TPP})_{2}$ and $\mathrm{U}_{2}^{\mathrm{III}}(\mathrm{TPP})_{3}$ during dissociation process (Figure 14) show a series of bands smoothly passing from the spectrum of the initial complex to another form of the complex: $(\mathrm{AcO})_{2} \mathrm{U}^{\mathrm{IV}}(\mathrm{TPP})$ and $\mathrm{U}^{\mathrm{IV}}(\mathrm{TPP})_{2}$, respectively. The spectra of the reaction mixtures contain in addition absorption bands of free porphyrin in protonated form $\mathrm{H}_{4} \mathrm{TPP}^{2+}$. The bands at 456 and $670 \mathrm{~nm}$ correspond to $\mathrm{H}_{4} \mathrm{TPP}^{2+}$. The reaction products were identified by UV-vis spectra after extracting the products from the reaction mixture, their purifying from $\mathrm{AcOH}$ traces and column chromatography on $\mathrm{Al}_{2} \mathrm{O}_{3}$ with $\mathrm{CHCl}_{3}$. The double-decker complex band at $516.0 \mathrm{~nm}$ (Figure 15) is absent in the absorption spectrum of product of its dissociation (AcO) ${ }_{2} \mathrm{U}^{\mathrm{IV}} \mathrm{TPP}$ (Figure 14). The UV-vis spectrum of $(\mathrm{AcO})_{2} \mathrm{U}^{\mathrm{IV}} \mathrm{TPP}$ is in agreement with the literature data for $(\mathrm{Cl})_{2} \mathrm{UTPP}^{[89]}$ 


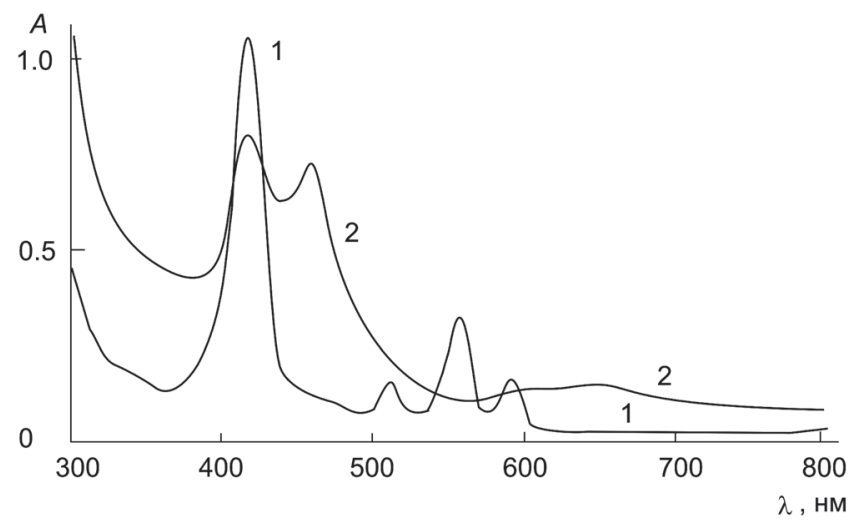

Figure 15. UV-vis spectra of $\mathrm{U}^{\mathrm{IV}}(\mathrm{TPP})_{2}$ in ethanol (1) and of $\mathrm{U}_{2}^{\mathrm{III}}(\mathrm{TPP})_{3}$ in benzene (2).

The above data allow suggesting the following reaction scheme of mutual transformations of different forms of uranium complexes (Figure 16).

The scheme is proved by the following experimental data. The acidocomplex ( $\mathrm{AcO})_{2} \mathrm{U}^{\mathrm{IV}} \mathrm{TPP}$ formation from $\mathrm{H}_{2} \mathrm{TPP}$ and $\mathrm{UO}_{2}(\mathrm{AcO})_{2}$ was not observed in benzonitrile, ticipation of the $4 f$-orbitals as well as the external $s$-orbitals is shown due to dependence, represented a concave curve with "gadolinium fracture", of the dissociation rate constants of the complexes $p k_{o b s}^{298}$ on the lanthanide ordinal number $Z$. The character of $p k_{o b s}^{298}-Z$ dependence for bis(phthalocyaninato) double-decker complexes is the same as ionization potential changing in the lanthanides row. A deep minimum for Gd and $\mathrm{Tb}$ complexes and higher stability of Eu complex in comparison with neighboring $\mathrm{GdPc}_{2}{ }^{\circ}$ are observed specifying on metal $f$-orbitals contribution in covalent Ln-N interaction. Spectrophotometric measurements of dissociation rate constants reveal not the ionic nature of tris(phthalocyaninato) triple-decker complexes dissociating in the same conditions with their acidophthalocyanine analogs. Like in the case of tris(phthalocyaninato) rare earth(III) triple-decker complexes the tris(meso-tetraphenylporphinato) thorium(III) triple-decker complex is less stable compared with double-decker complex. Full quantitative data about stability of phthalocyaninato/porphyrinato rare earth complexes in combination with the established scheme of transformations between different uranium complex forms are helpful for further fabricating of functional molecular materials based on compounds of this class.

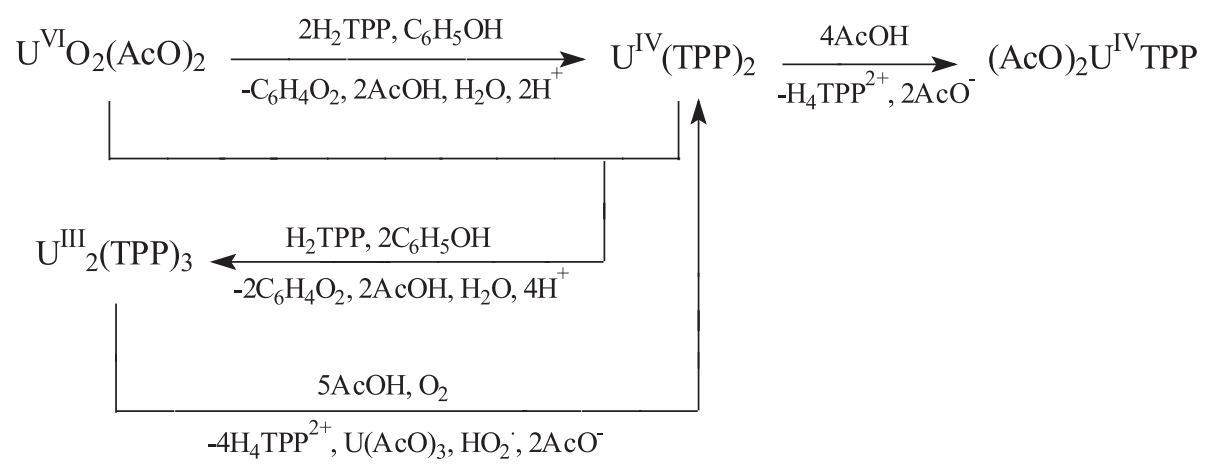

Figure 16. Scheme of transformations of different forms of uranium complexes.

phenol, or imidazole thought imidazole is the best medium for (X)LnTPP complexes formation. Two complex compounds, $\mathrm{U}^{\mathrm{IV}}(\mathrm{TPP})_{2}$ and $\mathrm{U}_{2}^{\mathrm{III}}(\mathrm{TPP})_{3}$, are formed faster in basic medium (phenol) than in benzonitrile. Phenol, being oxidized to quinone, promotes uranium(VI) reducing in initial $\mathrm{U}^{\mathrm{VI}} \mathrm{O}_{2}(\mathrm{AcO})_{2}$, to lower valent $\mathrm{U}^{\mathrm{IV}}$ state in which uranium cations can coordinate the porphyrin. Transformation of the double-decker complex $\mathrm{U}^{\mathrm{IV}}(\mathrm{TPP})_{2}$ into the triple-decker $\mathrm{U}_{2}{ }_{2}(\mathrm{TPP})_{3}$ is analogous to the mechanism of formation of similar phthalocyanine complexes. ${ }^{[97]}$

\section{Conclusions}

In summary, synthesis, structure, spectra and behavior in acids media of acidophthalocyaninato, bis(phthalocyaninato), tris(phthalocyaninato) and tris(porphyrinato) rare earth(III) double- and triple-decker complexes were described in detail. Covalent contribution to donor-acceptor interaction in acidophthalocyaninato complexes with par-
Acknowledgements. The described work was supported by the Russian Scientific Fund, the agreement № 14-23-00204.

\section{References}

1. Buchler J.W., Ng D.K.P. Metal Tetrapyrrole Double- and Triple-Deckers with Special Emphasis on Porphyrin Systems. In: The Porphyrin Handbook. Vol. 3. (Kadish K.M., Smith K.M., Guilard R., Eds.) Academic Press, 2000, pp. 246-294.

2. Lomova T.N., Klyueva M.E. Double- and Triple-Decker Phthalocyanines/Porphyrins. In: Encyclopedia of Nanoscience and Nanotechnology. V. X. (Nalwa H.S., Ed). ASP, 2004, pp. 565585.

3. Lomova T.N., Berezin B.D. Koord. Khim. 1993, 19, 171-184 (in Russ).

4. Sliwa W., Mianowska B. Transition Metal Chemistry 2000, 25, 491-504.

5. Puchkarev V.E., Tomilova L.G., Tomilov Yu.V. Russ. Chem. Rev. 2008, 77, 875-907.

6. Korovin Yu.V., Rusakova N.V. Rev. Inorg. Chem. 2001, 21, 299-329. 
7. Birin K.P., Gorbunova Yu.G., Tsivadze A.Yu. Dalton Trans. 2011, 40, 11539-11549.

8. Jiang J., Ng D.K.P. Acc. Chem. Res. 2009, 42, 79-88.

9. Kirin S., Moskalev P.N., Ivannikova I.V. Zh. Neorg. Khim. 1967, 12, 369-372 (in Russ.).

10. Moskalev P.N., Shapkin G.N., Darovskih A.N. Zh. Neorg. Khim. 1979, 24, 340-346 (in Russ).

11. Kirin S., Moskalev P.N., Makashev Yu.A. Zh. Neorg. Khim. 1965, 10, 1951-1953 (in Russ).

12. Misumi S., Kasuga K. J. Chem. Soc. Japan, Pure Chem. Section 1971, 92, 335-338.

13. MacKay G., Boas J.F., Troup G.J. Austr. J. Chem. 1974, 27, 955-964.

14. Kasuga K., Tsutsui M., Petterson R.S., Tatsumi K., van Ophenbosch N., Pepe G., Meyer E.F.Yr. J. Am. Chem. Soc. 1980, 102, 4835-4836.

15. Moussavi M., De Cian A., Ficher J., Weiss R. Inorg. Chem. 1988, 27, 1287-1291.

16. Ostendorp G., Werner J.-P., Homborg H. Acta Crystallogr., Sect. C: Cryst. Struct. Commun. 1995, 51, 1125-1128.

17. Haghighi M.S., Teske C.L., Homborg H. Z. Anorg. Allg. Chem. 1992, 608, 73-80.

18. Troyanov S.I., Lapkina L.A., Larchenko V.E., Tsivadze A.Yu. Dokladi Akademii Nauk 1999, 367, 644-648 (in Russ.).

19. Jiang J., Kasuga K., Arnold D.P. Sandwich-Type Phthalocyaninate and Porphyrinate Metal Complexes. In: Supramolecular Photosensitive and Electroactive Materials (Nalwa H.S., Ed.), Academic Press, New York, 2001, pp. 113-211.

20. Weiss R., Fischer J. Lanthanide Phthalocyanine Complexes. In: The Porphyrin Handbook, Vol. 16. (Kadish K., Smith R., Guilard R., Eds.), Academic Press, San Diego, 2003, pp. 171-246.

21. Bian Y., Zhang Y., Ou Z., Jian J. Chemistry of Sandwich Tetrapyrrole Rare Earth Complexes. In: Handbook of Porphyrin Science, Vol. 14 (Kadish K., Smith R., Guilard R., Eds.), World Scientific Publishing Co. Inc., New York, 2011, pp. 249-460.

22. Kadish K.M., Moninot G., Hu Y., Dubois D., Ibnlfassi A., Barbe J.M., Guilard R. J. Am. Chem. Soc. 1993, 115, 81538166.

23. Zhou Y., Zhang Y., Wang H., Jiang J., Bian Y., Muranaka A., Kobayashi N. Inorg. Chem. 2009, 48, 8925-8933.

24. Lu J.-T., Wang H.-L., Zhang X.-M. Chinese J. Struct. Chem. 2011, 30, 872-876.

25. Lomova T.N., Andrianova L.G., Sokolova T.N., Berezin B.D. Zh. Neorg. Khim. 1994, 39, 446-449 (in Russ.).

26. Jiang J., Bao M., Rintoul L., Arnold D.P. Coord. Chem. Rev. 2006, 250, 424-448.

27. Moskalev P.N. Koord. Khim. 1990, 16, 147-159 (in Russ.).

28. Ovseevich M.A., Tomilova L.G., Kogan E.G., Zefirov N.S. Mendeleev Commun. 1998, 186-187.

29. Qi D., Zhang L., Wan L., Zhang Y., Bian Y., Jiang J. Phys. Chem. Chem. Phys. 2011, 13, 13277-13286.

30. Senge M.O. The Porphyrin Handbook, Vol. 10 (Kadish K.M., Smith K.M., Guilard R., Eds.), Academic Press, 2000. 218 p.

31. Dubinina T.V., Paramonova K.V., Trashin S.A., Borisova N.E., Tomilova L.G., Zefirov N.S. Dalton Trans. 2014, 43, 27992809.

32. Pushkarev V.E., Tolbin A.Yu., Borisova N.E., Trashin S.A., Tomilova L.G. Eur. J. Inorg. Chem. 2010, 5254-5262.

33. Tolbin A.Yu., Tomilova L.G., Zefirov N.S. Uspekhi Khimii 2007, 76, $732-744$ (in Russ.).

34. Dubinina T.V., Pushkarev V.E., Trashin S.A., Paramonova K.V., Tomilova L.G. Macroheterocycles 2012, 5, 366-370.

35. Cao W., Wang H., Wang X., Lee H.K., Ng D.K., Jiang J. Inorg Chem. 2012, 51, 9265-9272.

36. Wang H., Wang K., Bian Y., Jiang J., Kobayashi N. Chem. Commun. 2011, 47, 6879-6881.

37. Wang H., Qian K., Wang K., Bian Y., Jiang J., Gao S. Chem. Commun. 2011, 47, 9624-9626.
38. Wang H., Kobayashi N., Jiang J. Chem. Eur. J. 2012, 18, $1047-$ 1049.

39. Wang H., Liu T., Wang K., Duan C., Jiang J. Chem. Eur. J. 2012, 18, 7691-7694.

40. Shang H., Wang H., Wang K., Kan J., Cao W., Jiang J. Dalton Trans. 2013, 42, 1109-1115.

41. Zhang X., Wang Q., Wu L., Lv W., Lu O., Bian Y., Jiang J. J. Phys. Chem. B 2010, 114, 1233-1240.

42. Zhang X., Li Y., Qi D., Jiang J., Yan X., Bian Y. J. Phys. Chem. B 2010, 114, 13143-13151.

43. Chen Y., Bouvet M., Sizun T., Gao Y., Plassard C., Lesniewskac E., Jiang J. Phys. Chem. Chem. Phys. 2010, 12, 12851-12861.

44. Li D., Wang H., Kan J., Lu W., Chen Y., Jiang J. Organic Electronics 2013 14, 2582-2589.

45. Zhang Y., Cai X., Bian Y., Jiang J. Organic Semiconductors of Phthalocyanine Compounds for Field Effect Transistors (FETs). In: Functional Phthalocyanine Molecular Materials Series: Structure and Bonding (Jiang J., Ed.) 2010, Vol. 135, pp. 275-322.

46. Ishikawa N. Phthalocyanine-Based Magnets. In: Functional Phthalocyanine Molecular Materials Series: Structure and Bonding (Jiang J., Ed.) 2010, Vol. 135, pp. 211-228.

47. Gao Y., Li R., Dong S., Bian Y., Jiang J. Dalton Trans. 2010 , 39, 1321-1327.

48. Lv W., Zhu P., Bian Y., Ma C., Zhang X., Jiang J. Inorg. Chem. 2010, 49, 6628-6635.

49. Takami T., Ye T., Pathem B.K., Arnold D.P., Sugiura K., Bian Y., Jiang J., Weiss P.S. J. Am. Chem. Soc. 2010, 132, 1646016466.

50. Zhu P., Zhang X., Wang H., Zhang Y., Bian Y., Jiang J. Inorg. Chem. 2012, 51, 5651-5659.

51. Kan J., Wang H., Sun W., Cao W., Tao J., Jiang J. Inorg Chem. 2013, 52, 8505-8510.

52. Huang C., Zhang Y., Sun J., Bian Y., Arnold D.P. J. Porphyrins Phthalocyanines 2013, 17, 673-681.

53. Dong S., Zhang X., Zhou Y., Jiang J., Bian Y. Dyes Pigm. 2011, 91, 99-104.

54. Bian Y., Wang R., Jiang J., Lee C.-H., Wang J., Ng D.K.P. Chem. Commun. 2003, 14, 1194-1195.

55. Lomova T.N., Volkova N.I., Berezin B.D. Zh. Neorg. Khim. 1987, 32, 969-974 (in Russ.).

56. Berezin B.D. Physical-Chemical Properties of Phthalocyanine Pigments in Sulfuric Acid Solutions. In: The Problems of Solution Chemistry. Concentrated and Saturated Solutions (Kutepov A.M., Ed.), Moscow: Nauka, 2002. pp. 145-169 (in Russ.) [Березин Б.Д. Физико-химические свойства сернокислых растворов фталоцианиновых пигментов. В кн.: Концентрированные и насыщенные растворы (Кутепов А.М., отв. ред.), М.: Наука, 2002. 455 с.].

57. Subbotin N.B., Tomilova L.G., Kostromina N.A., Luk'yanetz E.A. Zh. Obshch. Khim. 1986, 56, 397-400 (in Russ.).

58. M'Sadac M., Roncalay J., Carrier F. J. Chim. Phys. Phys.Chim. Biol. 1986, 83, 211-216.

59. Lomova T.N., Sokolova T.N., Mozhzhukhina E.G., Moskalev P.N., Berezin B.D. Zh. Fiz. Khim. 1992, 66, 1240-1245 (in Russ.).

60. Moskalev P.N. Certificate of authorship 525318 USSR. Bullenen' Isobreteniy 1978, N. 4 (in Russ.).

61. Lomova T.N., Andrianova L.G. Russ. J. Coord. Chem. 2004, 30, 660-664.

62. Lomova T. N., Andrianova L.G. Zh. Fiz. Khim. 2000, 74, $1587-$ 1592 (in Russ.).

63. De Chian A., Moussavi M., Fisher J., Weiss R. Inorg. Chem. 1985, 24, 3162 .

64. Ionova G.V., Vohnin G.V., Spitzin V.I. Regularities of Changes in the Properties of Lanthanides and Actinides. Moscow: Nauka, 1990. 238 p. (in Russ.) [Ионова Г.B., Boxмин В.Г., Спицын В.И. Закономерности изменения свойств 
лантанидов и актинидов. М.: Наука, 1990. 240 с.].

65. Meshkova S.B., Poluektov N.S., Topilova Z.M., Danilovich M.M. Koord. Khim. 1986, 12, 481-486 (in Russ.).

66. Lomova T.N., Andrianova L.G. Zh. Neorg. Khim. 1994, 39, 2011-2016 (in Russ.).

67. Lomova T.N., Sokolova T.N. In: Advances in Porphyrin Chemistry, Vol. 2 (Golubchikov O.A., Ed.), St.-Petersburg, 1999. pp. 167-189 (in Russ.) [Ломова Т.Н., Соколова Т.Н. В кн.: Успехи химии порфиринов, Т. 2 (Голубчиков О.А., ред), Санкт-Петербург, 1999. с. 167-189].

68. Bennett W.E., Broberg D.E., Baenziger N.C. Inorg. Chem. 1973, 12, 930 .

69. Janczak J., Kubiak R. Alloys Compd. 1994, 204, 5.

70. Darovsky A.N., Tsutsenko A.K., Frank-Kamenetskaya O.V., Fundamenskii V.S., Moskalev P.N. Kristallografiya 1984, 29, 455 (Chem. Abstr. 1984, 101, 46753e).

71. Yatzimirsky K.B., Kostromina N.A., Sheka Z.A., et al. Chemistry of Complex Compounds of Rare-Earth Elements, Kiev: Naukova Dumka, 1966. 495 p. (in Russ.) [Яцимирский К.Б., Костромина Н.А., Шека 3.А., др. Химия комплексных соединений редкоземельных элементов, Киев: Наукова думка, 1966. 494 с.].

72. Smola S.S., Snurnikova O.V., Fadeyev E.N., Sinelshchikova A.A., Gorbunova Yu.G., Lapkina L.A., Tsivadze A.Yu., Rusakova N.V. Macroheterocycles 2012, 5, 343-349.

73. Dubinina T.V., Pushkarev V.E., Trashin S.A., Paramonova K.V., Tomilova L.G. Macroheterocycles 2012, 5, 366-370.

74. Sokolova T.N., Lomova T.N., Morozov V.V., Berezin B.D. Koord. Khim. 1984, 20, 637-640 (in Russ.).

75. Janczak J., Kubiak R. J. Chem. Soc., Dalton Trans. 1993, 3809.

76. Kang Wang, Suyuan Zeng, Hailong Wang, Jianmin Dou, Jianzhuang Jiang Inorg. Chem. Front. 2014, 1, 167-171.

77. Martynov G., Zubareva O.V., Gorbunova Yu.G., Sakharov S.G., Nefedov S.E., Dolgushin F.M., Tsivadze A.Yu. Eur. J. Inorg. Chem. 2007, 4800-4807.

78. Birin K.P., Gorbunova Yu.G., Tsivadze A.Yu. J. Porphyrins Phthalocyanines 2011, 15, 667-673.

79. Kuz'mitzkiy V.A., Solov'ev K.N., Zvirko M.P. Spectroscopy and Quantum Chemistry of Porphyrins. In: Porphyrins: Spectroscopy, Electrochemistry, Application (Enikolopyan N.S., Ed.), Moscow: Nauka, 1987. pp. 7-126 (in
Russ.) [Кузьмицкий B.А., Соловьев К.Н., Цвирко М.П. Спектроскопия и квантовая химия порфиринов. В кн.: Порфирины: спектроскопии, электрохимия, применение (Ениколопян Н.С., ред), М.: Наука, 1987. с. 7-126].

80. Battisti D., Tomilova L., Aroca R. Chem Mater. 1992, 4, 1323 1328.

81. Lobanov A.V., Gromova G.A., Gorbunova Yu.G., TzivadzeA.Yu. Abstr. of XXXI Science Session of Russ. Sem. on Porphyrins and Analogs. Ivanovo. 2014, p. 70.

82. Moskalev P.N., Alimova N.I. Zh. Neorg. Khim. 1975, 20, 26642668 (in Russ.).

83. Mack J., Stillman M.J. J. Porphyrins Phthalocyanines 2001, 5,67 .

84. Mack J., Stillman M.J. Coord. Chem. Rev. 2001, 219-221, 9931032.

85. Sidorov N., Kotl'ar O.P. Opt. Spektrosk. 1961, 11, 175-184 (in Russ.).

86. Moskalev P.N., Mishin V.A., Rubtcov E.M., Kirin I.S. Zh. Neorg. Khim. 1976, 21, 2259-2262 (in Russ.).

87. M'Sadac M., Roncalay J., Carrier F. J. Electroanalyt. Chem. 1985, 189, 99.

88. Girolami G.S., Milam S.N., Suslick K.S. J. Am. Chem. Soc. 1988, 110, 2011-2012.

89. Girolami G.S., Milam S.N., Suslick K.S. Inorg. Chem. 1987, 26, 343-344

90. Lomova T.N., Andrianova L.G., Berezin B.D. Zh. Neorg. Khim. 1991, 36, 641-646 (in Russ.).

91. Girolami G.S., Gorlin P.A., Milam S.N., Suslick K.S., Wilson S.R. J. Coord. Chem. 1994, 32, 173-212.

92. BuchlerJ.W.,CianA.D.,FisherJ.,Kihn-BotulinskiM.,PaulusH., Weiss R. J. Am. Chem. Soc. 1986, 108, 3652-3659.

93. Lomova T.N., Andrianova L.G. Mendeleev Commun. 2003, 213-215.

94. Buchler J.W., Kapellmann H.G., KnoffM., Lay K.L., Pfeifer S.Z. Naturforsch., B: J. Chem. Sci. 1983, 38, 1339-1345.

95. Lomova T.N., Andrianova L.G. Russ. J. Phys. Chem. 2000, 74, 1432-1437.

96. Lomova T.N., Andrianova L.G., Berezin B.D. Zh. Neorg. Khim. 1989, 34, 2867-2872.

97. Leznoff C.C., Lever A.B.P. Phthalocyanines: Properties and Applications, Vols. 1, 2, 3 (Leznoff C.C., Lever A.B.P., Eds.), VCH: New York, 1989, 1990, 1992. 